\title{
Ethnic conflict and politics
}

Several significant ethnic conflicts have occurred in West Kalimantan since independence. The first took place in 1967, when hundreds or perhaps thousands of Chinese were murdered and more than 50,000 forced to flee from the interior areas now known as Landak and Bengkayang districts. A second, much smaller conflict between Dayaks and Madurese occurred in November 1979 in Samalantan (Bengkayang); members of both ethnic groups from about ten villages were involved, and the fighting lasted for about a week. Officials recorded 20 casualties and 50 houses burned down. Almost all Madurese evacuees were able to return to their homes after the conflict (Akcaya, 16-11-1979; Tempo, 8-12-1979). The third and fourth conflicts occurred in 1997 and 1999, and both involved the Madurese. The conflict in 1997 was between Madurese and Dayaks, while the 1999 conflict was initially between Madurese and Malays, although the Dayaks later joined the Malays. Human casualties were estimated to be above four hundred in each confrontation. Tens of thousands of Madurese fled the area, and there were untold material losses. A dozen smaller clashes between Dayaks and Madurese have taken place since the 1950s, mostly occurring in or around the Bengkayang and Landak districts.

This chapter attempts to analyse the causes of conflict between the Dayaks and Madurese by incorporating some new approaches and to identify the connections between ethnic conflict and ethnic politics.

\section{CHRONOLOGY OF THE DAYAK AND MADURESE CONFLICT} IN 1997

This conflict started with a street fight between Dayak and Madurese youths during a pop concert in the town of Ledo (Bengkayang) on 6 
December 1996. A Dayak, Yukundus, was reported to have approached Madurese youths and requested that they stop bothering a Dayak girl. The Dayak struck some Madurese after they ignored his warnings. One of the Madurese was Bakrie. More serious fighting did not develop that night, but about three weeks later the groups encountered each other again at a band concert in Tanjung village (Ledo). When Yukundus and another Dayak were attacked by Bakrie and friends in the early hours of 30 December, the Dayaks were injured and rushed to a nearby hospital where they were treated and later discharged. ${ }^{1}$

The same morning, a Dayak crowd started to gather at the Ledo police station to demand the arrest of the perpetrators. The police had made some arrests that morning but did not announce them for fear the crowd would storm the station and lynch the suspects. The crowd grew larger as people did not obtain a satisfactory answer from the police. Later in the afternoon the crowd marched all the way up to Sanggau Ledo sub-district to look for Bakrie, who lived in Lembang village (Sanggau Ledo). On the way they burned several Madurese houses and injured one Madurese. In the evening of the same day, the army in Bengkayang fired shots at the Dayaks, who tried to attack the military post, where they believed the Madurese were being held. The Dayaks acted on false rumours that the Madurese were preparing for retaliatory attacks.

The following day the military shot at Dayaks who tried to attack a Bengkayang military compound in which the Madurese had taken refuge. Although only three Dayaks were injured, rumours that they had been killed spread to surrounding areas. Madurese homes in villages in Samalantan and Tujuh Belas sub-districts were attacked and burned as a result. Meanwhile, because of the growing tension and threat, the security forces started to evacuate Madurese who lived in Sanggau Ledo to a nearby air force base.

Based on past experiences, Dayaks believed that the Madurese retaliation was only a matter of time. ${ }^{2}$ On one occasion, a large Madurese crowd in Lembang village had already prepared to attack the Dayaks

\footnotetext{
1 These accounts, which were widely quoted in the media, were most likely from the Dayak side. The author was not able to find Madurese accounts of this incident. However, judging from their accounts of the 1999 conflict, the Madurese would give an account favourable to themselves (see note 5 below).

In several conflicts with the Dayaks prior to 1997, the Madurese always struck back or at least planned to retaliate (Tempo, 8-12-1979, Sudagung 2001:129, 141-2; Van Hulten 1992:296).
} 
in Sanggau Ledo before they were persuaded by the head of Sanggau Ledo Customary Council and security forces to withdraw to Singkawang (Soetrisno et al. 1998:34). The Madurese from nearby Singkawang who finally took the initiative to counterattack, and on the two days of fighting, the Madurese burned at least two houses belonging to prominent Dayaks (Paulus Lopon Piling, a Dayak entrepreneur, and Antonius Alim, a Dayak official) in Singkawang, and seriously injured one Dayak.

These Madurese retaliations triggered further Dayak attacks on the Madurese and their properties. Evacuation of the Madurese out of the affected area continued. The burning of Madurese houses did not stop at least until the end of first week of January 1997, when no more houses were left to burn. The military dropped leaflets from aircraft over the affected areas, including the sub-districts of Tujuh Belas, Bengkayang, Ledo, Sanggau Ledo, Seluas, Sambas, Pemangkat and Tebas. The leaflet informed the population that everything was under control and urged people not to believe rumours, carry weapons or engage in criminal activities. By 6 January 1997 the situation apparently had returned to normal (Soetrisno et al. 1998:34). From 5 to at least 8 January, the government sponsored peace ceremonies between the Dayaks and Madurese in several conflict-affected sub-districts. By this time, 6,075 Madurese had evacuated, more than 1,000 houses had been torched, and about 20 Madurese were reported killed.

The relatively calm but tense second and third weeks in January were broken by a Madurese attack on buildings associated with Dayak interests in Pontianak in the early morning of 29 January 1997. The credit union and the student dormitory, both belonging to Pancur Kasih Foundation, an influential Dayak institution, were slightly damaged. A motorcycle and a truck belonging to the Foundation were also burned. No deaths occurred, but two female Dayaks, who boarded in a neighbouring house, were injured during the attacks. The Human Rights Watch (HRW) report linked the attack to an incident in a village in Tujuh Belas sub-district the day before, when a crowd of Dayaks burned down houses and a prayer hall (surau). ${ }^{3}$ An unfounded and absurd rumour that Habib Ali, a Madurese religious leader, had been killed by Dayaks in the

3 The HRW report mentioned that the attack was in Sakek (possibly a typo of 'Sakok', a part of Sedau village, south Singkawang sub-district) (Communal violence West Kalimantan 1997). If this attack on Pancur Kasih was truly linked to the previous attack in Sakok, then the second episode was started by the Dayaks, not the Madurese as had been reported. 
outskirts of Pontianak might also have helped to ignite to the attack. ${ }^{4}$ Meantime, the Madurese in Mempawah, 67 kilometres from Pontianak, set ablaze three Dayak houses and damaged another. On 30 January, the Madurese set up a roadblock in Peniraman, a small town 32 kilometres north of Pontianak. During the two-day operation, five Dayaks were killed. On 1 February, in Singkawang, Madurese killed a Dayak, burned down four houses and damaged six Dayak houses.

The Dayaks retaliated by setting up similar roadblocks between Mempawah and Ngabang, and these resulted in Madurese deaths. Raids on the Madurese and their property intensified and became more vicious. The deadliest attacks occurred in the present Landak district: in Pahauman with 148 Madurese deaths and in Salatiga where 131 Madurese were killed. The military started to adopt harsh measures to stop further conflict escalation including shooting on several occasions (on 2 February in Samalantan (Bengkayang district) and on 3 and 5 February in Anjungan (Pontianak district)). Soetrisno et al. (1998:41-4) estimate that more than 125 Dayaks were shot dead by the security forces in several incidents.

This second episode started at the end of January and caused more damage, with death tolls estimated at between 500 and 1,700, and the majority of fatalities on the Madurese side (Davidson 2002:231). The fighting also spread to larger areas and included areas which had been untouched by previous conflicts, such as Sanggau. At least 142 Madurese were killed in Sanggau district in Sosok (47), Tayan (54), and Karangan (41). The spread of the attacks to other districts was a sign of the growing idea of a shared destiny among the Dayaks because they had all suffered similar marginalization and oppression (Davidson 2002:244-5).

\section{CHRONOLOGY OF THE MALAY/DAYAK AND MADURESE CONFLICT IN 1999}

The conflict in 1999 could be traced back to an assault on a Madurese, Hasan bin Niyam, on 17 January 1999. He was accused of breaking and

\footnotetext{
4 Absurd, because it was very unlikely that the minority Dayaks in Pontianak City would provoke conflict with the more dominant Madurese. The Dayaks in Pontianak City were always on the defensive in the conflict.
} 
entering a Malay house in Parit Setia village, Jawai (Sambas). ${ }^{5}$ Two days later, on the day of the Muslim Idul Fitri festival, around 200 Madurese from the nearby Rambayan village, where Hasan lived, took revenge. They killed three Malays and fatally wounded two others. ${ }^{6}$ The incidents did not spread further because Muslims were still celebrating Idul Fitri. Government and security forces responded immediately to calm the conflicting parties. They arranged a peace meeting on 23 January in Jawai between ethnic leaders from the two affected villages, where they were persuaded to surrender the perpetrators from both sides. The Malays surrendered eight people involved in the bashing of Hasan, while the Madurese surrendered one who was involved in the killing of the three Malays (Akcaya, 23-1-1999; Purwana 2003:59). A week after the incident, conditions in Jawai had reportedly returned to normal (Akcaya, 27-1-1999). However, both communities continued to be vigilant and conducted night watches for fear of possible counter-attacks from the other side.

On 21 February 1999, in Mensere, Tebas sub-district (Sambas), Bujang Labik bin Idris, a Malay, was injured by a Madurese, Rudi bin Muharrap. A short time before the attack, Bujang was in the same minibus with Rudi. Rudi felt offended by Bujang's stare when Rudi got off the bus without paying the fare. He was able to stop the same bus on its way back and wounded Bujang in revenge. ${ }^{7}$

News of the wounding of Bujang spread to surrounding areas. The next morning, around 300 Malay youths surrounded the perpetrator's house in Sempadung, Tebas (Sambas), demanding he surrender to the police. The conflict broke out when a Malay demonstrator was shot during the siege. Riots ensued in some nearby villages such as Semparuk and Sungai Kelambu where many Madurese houses were burned down. Three deaths were recorded by the morning of 22 February (Davidson 2008:133). On the night of 23 February, bands of Malays tried unsuc-

\footnotetext{
5 One Madurese source denied the accusation and claimed that the man with his two friends was actually looking for a place to sleep. They knocked at the door and flashed their sickles when the owner opened the door. The owner suspected robbery and cried for help. The neighbour was able to capture one Madurese, while the others escaped (Purwana 2003:58).

Davidson (2002:294) explains that Rambayan was a village but was reduced to dusun (sub-village) status during the village reorganization at the beginning of the 1980s. Rambayan dusun became a part of Sari Makmur village.

7 Interview with Bujang in Kapuas, 15-4-1999. One source mentions another incident on the same day in Sungai Nyirih village, Jawai (Sambas), where a Madurese wounded a Malay. The Malay was taken to Matang Suri health clinic, Jawai (Purwana 2003:61).
} 
cessfully to attack Tebas police station where 200 Madurese had taken refuge (Davidson 2008:133).

The government arranged peace talks between the Madurese, Malay, and Dayak leaders in Tebas and then in Pemangkat sub-districts on 23 and 24 February. Despite these peace talks, conflicts spread to the adjacent Pemangkat, Jawai, and Sambas sub-districts. The riots between 23 and 25 February 1999 witnessed 17 deaths, 65 houses burn down, and around 200 Madurese taking refuge in the Sambas police station (Purwana 2003:62-3).

On 14 March, a Madurese who refused to disarm himself in Pemangkat triggered another wave of conflict that spread to Sungai Duri, Teluk Keramat, and Paloh (Akcaya, 16-3-1999). Malays in Sambas sub-district, who had not been involved in the conflict, joined the assault after Malay villages there were attacked by Madurese (Akcaya, 21-3-1999; Petebang and Sutrisno 2000:12). Because of this new development many Madurese who had not left the area were urged by local leaders to evacuate (Akcaya, 21-3-1999). From this point on, the evacuation continued until virtually all Madurese were evacuated from Sambas (Petebang and Sutrisno 2000:8).

Dayaks joined the attack against the Madurese in Bengkayang district after a Dayak of Samalantan was killed on 17 March by a group of people speaking Madurese. ${ }^{8}$ The Dayaks started to burn houses in Sanggau Ledo and Samalantan sub-districts. Conflict spread further inland, which prompted the Madurese evacuation out of Bengkayang, Ledo, and Sanggau Ledo. Then the Dayaks tried to get into Singkawang City which held a large number of Madurese refugees but were prevented from entering by the military.

As the conflict grew to uncontrollable proportions, military and police commanders allowed soldiers to open fire on the masses who did not comply with their instructions (Akcaya, 19-3-1999). Two units from East Kalimantan and one unit from South Kalimantan arrived to help secure

\footnotetext{
8 Martinus Amat, the victim, was travelling back from work with a group of 23 passengers, the majority of whom were Dayaks, with only one Malay and one Batak driver. The packed open truck was fired on by a mob who were speaking in Madurese (Purwana 2003:66; Petebang and Sutrisno 2000:8). This latest Madurese attack dragged the Dayaks into the conflict as a consequence of their strong belief that the Dayaks were helping the Malays in the conflict (Petebang and Sutrisno 2000:30). This is still shown in a recent survey in Madura where the Sambas refugees still talk about Dayak hostility rather than Malay hostility, and state that the conflict was a religious conflict (Wiyata 2003). Another source, however, suggests that the killing of Amat as suspicious and the security forces (Davidson 2002:308).
} 
the standoff (Akcaya, 21-3-1999). On 22 March, security forces guarding the refugee evacuation shot at approaching Malay mobs in Tebas (Akcaya, 23-3-1999). Another shooting aimed at a Malay crowd occurred on 7 April and resulted in some casualties (Akcaya, 8-4-1999).

On 24 March, newspapers reported that some semblance of normalcy had been restored, with shops in Singkawang, Pemangkat, Tebas, and Sambas re-opening for business (Akcaya, 25-3-1999). There were reports of attacks or failed attacks in Singkawang and Sungai Raya (south of Singkawang) in April (Akcaya, 8-4 and 23-4-1999). The attacks in Sambas district had subsided by the end of March, because most of the Madurese in the district had taken refuge or were under the protection of security forces for evacuation to either Singkawang or Pontianak.

By 13 April 1999, official data from the Sambas government listed 416 deaths (401 Madurese, 14 Malays, and 1 Dayak); 4367 Madurese houses, 22 Malay, and 21 others burned down; 345 houses - the majority belonging to the Madurese - damaged (Purwana 2003:68, 70). By 3 August, official statistics noted that Pontianak refugee camps had around 15,907 refugees (Purwana 2003:72).

HISTORICAL, MARGINALIZATION AND CULTURAL ARGUMENTS

A peculiarity of many ethnic conflicts in West Kalimantan up to 1997 was that they always involved Dayaks and Madurese. Conflicts between them had occurred more than ten times since the 1950s. ${ }^{9}$ Other important ethnic groups such as Chinese, Javanese or Malays experienced episodes of violence, but the open conflicts seem to be only between the Dayaks and the Madurese (Davidson 2002:244). This fact suggests that there some specific causes must exist on both sides, which have made conflict flare up and deepen between them.

\section{HEADHUNTING AND HISTORY OF CONFLICT}

The Dayaks' past traditions of headhunting and traditional war mobilization were sometimes used to explain the many conflicts occurring in Dayak territory. The argument that conflict is derived from Dayak

9 Davidson 2008:89-90; Petebang 1998:79-80; Giring 2003:128-9; Van Hulten 1992:296-7. 
traditions is, however, unconvincing as there were fundamental differences between the headhunting practices in the past and that practiced during the recent conflicts (Peluso and Harwell 2001:85). Traditionally headhunting was considered necessary to protect tribes and their villages from disaster and misfortune, to avenge their fallen victims or fighters or to increase a warrior's spiritual power and pride (Ukur 1971:59-60; Bamba 2004:138). The heads obtained were valued highly and treated with respect. Ceremonies were held to express respect for the heads, so that spiritual aims could be reached (Petebang 1998:1-36). Traditional headhunting's strong spiritual and cultural content was much more important than the elimination of enemies.

Modern headhunting lacks the spiritual or cultural content. Contemporary Dayak mobs were not constrained by traditions and customs, which according to Petebang (1998) guided past headhunting expeditions. Traditional symbols were ignored or even damaged during the conflicts by the angry Dayak mobs. As the mobs had no faith in the traditional systems, those who claimed that the decapitation of victims during more recent conflicts was a revival of the headhunting tradition are incorrect. Rejection of the role of headhunting was underscored by the 1999 conflict in which the Malays, who did not have this tradition, took Madurese heads. This modern 'headhunting' is actually a form of mutilation, a means to dehumanize the victim as an expression of hatred and animosity. ${ }^{10}$

Traditional war mobilization was also often associated with previous ethnic conflicts involving the Dayaks. The Kanayatn Dayak for example passed (mengedarkan) red bowls in times of war and emergency. ${ }^{11}$ Villages that received the bowl were required to send help and to pass the bowl on to other villages without delay (Petebang 1998:69-78). The last significant use of the red bowl was during the 1967 outbreak of violence between the Dayaks and the Chinese. Although people believed that the red bowl was in circulation in some areas during the 1997 conflict, the

1o For various meanings and reasons behind the mutilation of the victim's body, see Horowitz (2001:11-23).

1 Red bowls were a means of communication among the Kanayatn Dayaks that usually consisted of four elements: the blood of an animal, feathers, a match stick, and a piece of roof thatch. The blood signified the critical conditions/war. The other elements mean that word of the war must be passed quickly (the feather) from one village to another, even in darkness (the match) or bad weather (the thatch). Further on the red bowl referred to Petebang (1998). For Dayak Desa a quite similar practice was called Damak/Patuong and for Iban it was Bungae farao (Arafat 1998:139). 


\begin{tabular}{|c|c|c|}
\hline Year & Location & Initial causes \\
\hline 1950 & Samalantan (Bengkayang) & Fight between a Dayak and Madurese. \\
\hline 1952 & (No location given) & $\begin{array}{l}\text { Theft of a Dayak's bubu (fish trap) by a } \\
\text { Madurese. }\end{array}$ \\
\hline 1967 & Toho (Pontianak) & $\begin{array}{l}\text { Murder a parent of a Dayak sub-district head } \\
\text { of Toho. }\end{array}$ \\
\hline 1968 & Anjungan (Pontianak) & $\begin{array}{l}\text { Murder of a Dayak sub-district head of } \\
\text { Sungai Pinyuh. The Dayak had refused to } \\
\text { process the Madurese request to process a } \\
\text { land-ownership application. }\end{array}$ \\
\hline 1976 & Sungai Pinyuh (Pontianak) & $\begin{array}{l}\text { Murder of a Dayak by a Madurese who was } \\
\text { cutting grass on the Dayak's land. }\end{array}$ \\
\hline 1977 & Singkawang & $\begin{array}{l}\text { Killing of a Dayak policeman by a Madurese. } \\
\text { The Dayak cautioned his sister not to go out } \\
\text { at night with the Madurese. }\end{array}$ \\
\hline 1979 & Samalantan (Sambas) & $\begin{array}{l}\text { Murder of a Dayak by a Madurese. The } \\
\text { Dayak asked the Madurese to be cautious } \\
\text { when cutting grass so as not to disturb the } \\
\text { paddy. }\end{array}$ \\
\hline 1982 & $\begin{array}{l}\text { Pakucing (Samalantan, } \\
\text { Bengkayang) }\end{array}$ & $\begin{array}{l}\text { Murder of a Dayak by a Madurese. The } \\
\text { Dayak cautioned the Madurese because he } \\
\text { did not ask for permission to cut grass on the } \\
\text { Dayak's land. }\end{array}$ \\
\hline 1983 & $\begin{array}{l}\text { Sungai Enau (Sungai } \\
\text { Ambawang, Pontianak) }\end{array}$ & $\begin{array}{l}\text { Murder of a Dayak by a Madurese because of } \\
\text { a land issue. }\end{array}$ \\
\hline 1992 & $\begin{array}{l}\text { Pakucing (Samalantan, } \\
\text { Bengkayang) }\end{array}$ & Rape of a Dayak woman by a Madurese. \\
\hline 1993 & Pontianak City & Fight between Dayak and Madurese youths. \\
\hline 1994 & Tumbang Titi (Ketapang) & $\begin{array}{l}\text { Stabbing of a Dayak by a Madurese road con- } \\
\text { struction worker }\end{array}$ \\
\hline 1996 & $\begin{array}{l}\text { Started in Sanggau Ledo } \\
\text { (Bengkayang) and spread } \\
\text { to other districts }\end{array}$ & Fight between Dayak and Madurese youths. \\
\hline 1997 & $\begin{array}{l}\text { Started in Pontianak City } \\
\text { and spread to other district }\end{array}$ & $\begin{array}{l}\text { a Madurese youth attack on the Pancur Kasih } \\
\text { complex }\end{array}$ \\
\hline 1999 & $\begin{array}{l}\text { Started in Jawai (Sambas) } \\
\text { and spread to other dis- } \\
\text { tricts }\end{array}$ & $\begin{array}{l}\text { Conflict between Malays/Dayaks and } \\
\text { Madurese. }\end{array}$ \\
\hline
\end{tabular}

Table 7.1 Dayak - Madurese conflicts in West Kalimantan (1950-1999) Sources: Giring (2003:128-9); Abas (2002:3-4); Davidson (2008:89-90). 
red bowl could not have been responsible for the spread of violence. The advancement of communication technology (such as telephone, mobile phone), better roads and modern faster transportation had taken over the function of the red bowl. however, the use of ethnic symbols (in this case the red bowl) in ethnic conflicts has a powerful emotional appeal to members of the ethnic group and therefore, the potential to intensify conflicts (Kaufman 2001:29).

The recent history of ethnic relations between Dayaks and Madurese offers better explanations for friction between the two groups than do ancient Dayak traditions of warfare. he series of conflicts between them confirmed both views that they have had conflictual relations. The groups accused each other of being the trouble makers. The perception that the Madurese were violent was widespread among the Dayaks. ${ }^{12}$ A survey of 100 Dayak informants conducted by Muhamad Abas found that 86 per cent of them believed the Madurese were evil-doers. However, most of them had only heard of the negative behaviour of the Madurese and only 16 per cent of them had seen or experienced directly any Madurese misdeeds (Abas 2002:84). When they were questioned, the Dayaks would give a list of conflicts with the Madurese to substantiate their claims.

\section{MARGINALIZATION ARGUMENTS}

Chapter 6 noted some problems associated with transmigration, logging, and plantation activities in rural regions. Encounters between the 'elite' Dayaks in both rural and urban area with immigrants created frustration that had been simmering under the surface due to the repressive nature of the New Order regime. Retribution from the government officials and security forces on those who oppose government projects or policies was not uncommon (Dayak leaders' memories 2005:3, 8). The tension and dissatisfaction among local Dayak farmers as a result of development projects certainly existed back in the 1980s when large plantation operations started to have an effect. ${ }^{13}$ In 1981, five Dayak vil-

\footnotetext{
12 The Madurese argument for blaming the Dayaks was weakened considerably when the Malays also 'found' that the Madurese were the problem during the 1999 conflict.

13 Local opposition to logging activities seems to have been less than Dayak discontent with plantations mainly because logging offered quick cash to the local population. This quick cash partly explains why it has been very difficult to stamp out illegal logging in this region.
} 
lage chiefs from Sayan (Sintang) met with the local DPRD members to demand compensation for their tengkawang (illipe nut) trees that had been felled by a logging company (Davidson 2002:265). Several sources, for instance, mention the objection of some Dayak leaders, including the former Governor Oeray, to the government's unfair financial compensation for the confiscated land in Meliau at the beginning of the 1980s. The government response was to change the local Dayak sub-district head, Donatus Djaman, and then warn the eleven local Dayak leaders of possible disciplinary action (Dayak leaders' memories 2005:8; Golkar Sanggau 1981).

The 1990s witnessed more confrontational protests by Dayak farmers, as a result of unresolved grievances, consciousness-raising activities from Dayak NGOs, and the weakening of the Soeharto regime. Davidson (2008:114-5) and Andasputra (1999) have given several accounts of these demonstrations. In September 1993, in Mukok (Sanggau), fourteen Dayaks burned employee lodgings belonging to a plantation company because it failed to compensate local people. In August 1994 in Sandai (Ketapang), around 1,600 Dayaks burned down ten base camps, vehicles and other materials, as well as ten hectares of land belonging to a plantation company. In November 1995, 300 Dayaks destroyed the seedlings of a plantation company in Ledo (Sambas).

Davidson (2008:95) rightly questions the link between marginalization and open conflicts between Dayaks and Madurese, because the confrontations did not occur in areas of transmigration or in areas with an extensive of logging and plantation operation. Peluso and Harwell also argue that organized transmigration cannot be blamed automatically for the conflict (Peluso 2006:117). Furthermore, the Madurese were not the main or primary cause for Dayak political and economic marginalization. While there might be no direct link between these activities and Dayak-Madurese conflicts, marginalization produced a feeling among many Dayaks that they were being oppressed and many migrants receiving favourable treatment. This shared marginalization among the Dayaks strengthened ethnic solidarity that can be seen to contribute to the spreading or intensification of conflicts (Eklöf 1999:66; Olzak 1992:21). As in a pressure cooker, the higher the disappointment and frustration the stronger the force it will create when finally released. 
ETHNIC STEREOTYPES

The Madurese have been negatively stereotyped by the other natives of Indonesia as a rough, aggressive, and violent ethnic group since colonial times (De Jonge 1995:9-13; Smith 2004:207). One scholar who has undertaken extensive study on the Madurese even remarked that this ethnic group has a plenitude of negative characteristics (De Jonge 1995:7). These negative perceptions have been widely believed to by the local population and have influenced their daily interactions with the Madurese for many years.

A Madurese scholar concludes that one cause underlying the Madurese violent character was a social system that respected and rewarded violence - particularly if it was carried out in order to protect one's dignity. ${ }^{14}$ Crime statistics suggest that the Madurese community is generally more violent than other ethnic groups in Indonesia because of the higher incidence of serious crimes in Madura Island. Serious criminal cases in Madura in 1994 were double the rate of East Java, and one-and-a-half times higher than the national average (Wiyata 2002:6).

This stereotype of Madurese was widely accepted by other ethnic groups in West Kalimantan. One survey found that the Dayaks stereotyped the Madurese as being fond of fighting (violent), emotional, untrustworthy, and cowardly (Arafat 1998:273). Other research summarizes broadly three stereotypes of the Madurese by the Dayaks and Malays. First, the Madurese tended to initiate conflict with others. Second, the Madurese had the custom of carrying the sickle (clurit) at social functions or upon entering someone's house. ${ }^{15}$ Thirdly, the Madurese were inclined to encroach on their neighbour's land. ${ }^{16}$ The Madurese were also often associated with unscrupulous economic practices and petty

${ }_{14}$ One example of such a system is the carok, a duel to the death between Madurese men to protect the dignity of oneself or one's family. This practice is still found within the Madurese community (Wiyata 2002:1, 73, 226-7).

${ }_{15}$ Wherever he goes, the Madurese usually carries a clurit, a sickle-shaped knife used to collect grass for their cattle. Madurese farmers were known for their skill in raising cattle, and the 1990 census showed that the Madurese were prominent in the livestock sector in Sambas and Ketapang.

16 Purwana 2003; Davidson 2002:238-9; Soetrisno et al. 1998; Abas 2002:81-5; Suparlan et al. 1989:65-6. 
crimes (Soetrisno et al. 1998:61-2). A few well known local sayings mock unacceptable Madurese behaviour. ${ }^{17}$

Negative perceptions of other ethnic groups are common too but usually not related to violent attitude as is the stereotype of the Madurese. Some ethnic groups perceived the Dayaks as backward and lazy, and sometimes violent because of their reputation for headhunting. The Chinese were greedy and dishonest in doing business, while the Malays were lazy and untruthful. ${ }^{18}$

The majority of Dayak informants believed that the particularly easily provoked, violent and insensitive dispositions of the Madurese were the main factors behind many conflicts between them. Several conflicts started with Madurese unjustified attacks on Dayaks that resulted in a Dayak death or injury. ${ }^{19}$ During recent conflicts, the media reports and government statements reinforced the image of Madurese as troublemakers. The media was usually critical of or biased against the Madurese and blamed them for causing the conflicts. Government officials were reported to have identified Madurese culture as the source of violent conflicts. ${ }^{20}$

The perception that Madurese were violent and hot-tempered produced a growing fear of the Madurese among local communities. This fear made existing communities move away from Madurese settlements, such as what happened to the Dayaks in Salatiga village (Giring 2003:31) or the Malays in Sari Makmur village (Abas 2002:82). These villages eventually became Madurese-dominated villages because of increasing Madurese migrant numbers and the gradual departure of the original inhabitants. Local populations might also decide to limit social contact

${ }_{17}$ One popular saying was 'The land boundary could walk' refers to the Madurese practice of enlarging their land size by surreptitiously changing the boundaries. Another saying, 'young chickens belong to us; when they grow up they belong to them' refers to the Madurese thieving habit. These sayings have been in existence for decades. For example, a newspaper article in 1978 (Akcaya, 13-2-1978) used the same terms when it referred to the unsafe condition in Rambayan A, a village close to Madurese quarters, which was also a site for the 1999 conflict.

18 Tohardi 2003:40-4; Alqadrie 1990:98-9; Lontaan 1975:39; Abas 2002:86-7.

19 Unfortunately all explanations seem to favour the Dayaks as there are no alternative explanations that favour the Madurese.

2o Davidson (2002:311) even asserted that not a single politician or government official he encountered defended the Madurese during the 1999 conflict. Prior to 1997, the government had never attributed conflicts to ethnic factors out of fear that such an attribution might complicate ethnic relations in the province. They usually did not mention ethnic aspects of any conflict and always downplayed the event by describing it as a common crime (kriminal biasa) or incident (kejadian or peristiwa) rather than conflict (konflik or kerusuhan) (Tempo, 8-12-1979; Akcaya, 16-11-1979; Davidson 2002:224). 
with the Madurese out of fear or to avoid trouble. A local researcher gives an example of Malays in Sambas who made the Madurese village a no-go zone for themselves, especially after dark. ${ }^{21}$ Another researcher mentions that fear of the Madurese had helped them to take over the Pontianak bus terminal, which had previously been controlled by Batak thugs (Petebang and Sutrisno 2000:145). Even the police were reportedly reluctant to handle petty crimes committed by the Madurese, and they would release the Madurese criminals once they had been approached by the Madurese family or friends.

Such fear of the Madurese made them feel more powerful than locals, And they did not see the need to show respect to the local people or to follow local customs (Petebang and Sutrisno 2000:145). Many Dayaks believed that the Madurese viewed them as easy targets of violence and crime, because otherwise they would not have started a dozen conflicts with the Dayaks. Local scholars believe that it was this constant fear and history of conflict that made the Madurese a concrete representation of threat in the Dayaks' daily interactions with them. ${ }^{22}$

\section{MADURESE DEMOGRAPHY AND SETTLEMENT TRENDS}

Some regions in the province, particularly the north-west regions, were particularly prone to conflict, while others such as Ketapang, Sintang and Kapuas Hulu districts were spared. Ethnic concentration and exclusive settlements may have contributed to the conflict. In the case of the Madurese, because of negative stereotypes and history of conflict, their close proximity to the Dayaks increased fear among the Dayaks. Background or origin of the Madurese migrants and the large amount of in-migration may have contributed to the conflicts.

The first serious encounter of the local population with the Madurese was probably when the Dutch government sent 500 to 600 Madurese

\footnotetext{
${ }^{21}$ Purwana 2003:46. Because of tense relationships between the two ethnic groups, intermarriage between them was rare. In Salatiga, a village with about 1200 Madurese and 200 Dayaks, Giring (2003:101) only found one case of intermarriage.

${ }_{22}$ Petebang and Sutrisno 2000; Giring 2003; Soetrisno et al. 1998:61-2. As stereotyping ignores individual differences within a group as noted by Cashmore (2004:414) and Yang (2000), the whole Madurese community had to bear the cruel consequences of prejudice during the various conflicts.
} 
auxiliary troops to quell Chinese unrest in Monterado in $1854 .^{23}$ The numbers of the Madurese in the province totalled only 631 by 1920 . Within ten years, based on the 1930 census, this figure jumped to 5,763. The highest concentration was in the divisions (afdeelingen) of Pontianak, Singkawang, and Ketapang. At this stage, the Madurese were already the sixth largest ethnic population in the province, after Dayaks, Malays, Chinese, Bugis, and Javanese. Before 1999 the largest concentrations of Madurese were found in Pontianak City, Pontianak, Sambas and Ketapang districts, roughly resembling their pre-independence demographic condition. On the other hand, interior districts remained unattractive for the Madurese settlers. According to the 2000 census, Sanggau district only had 1,483 Madurese or 0.29 per cent of total district population, Sintang 286 persons or 0.06 per cent, Kapuas Hulu 52 persons or 0.03 per cent. ${ }^{24}$

The ethnic demography in the northern districts of West Kalimantan changed dramatically after the conflict of 1999 because of the disappearance of the Madurese. Sambas district was virtually cleansed of the Madurese, while many interior regions of the current Bengkayang and Landak districts also were cleared of Madurese. According to the 2000 census, the Madurese population in Sambas was only 0.017 per cent of the total district population (or only 75 persons), in Bengkayang it was 1.15 per cent (or 2,039 persons), and in Landak it was 2.13 per cent. This was in sharp contrast with the data in 1990, where the Madurese population in Sambas (including Bengkayang) was about 4.2 per cent and in Pontianak district (including Landak) 12.7 per cent.

Hostilities between Dayaks and Madurese have only occurred in districts with a significant concentration of both Madurese and Dayaks. The small Madurese population in the interior regions might be the reason for the virtual absence of conflict there. One exception was the attacks of the Madurese in Sanggau during the 1997 conflict. The Madurese population in the Sanggau district, although relatively small compared to other districts, had increased quite significantly from 427

23 Heidhues 2001:144, 148. The Dutch had been employing the Madurese to put down revolts throughout Dutch East Indies since the eighteenth century (Kuntowijoyo 1988:144-7; Smith 2004:208). ${ }_{24}$ The numbers of Madurese in the upper Kapuas districts had not changed much. The conflicts in recent time had not only stopped what already small flow of Madurese to this region, but also forced many to leave the region. The Madurese population in Sanggau, for example, was estimated at 4,800 between 1997 and 1998 (Arafat 1998:177) or about 1 per cent of the district population, but almost 70 per cent of them had left the district by 2000 . 


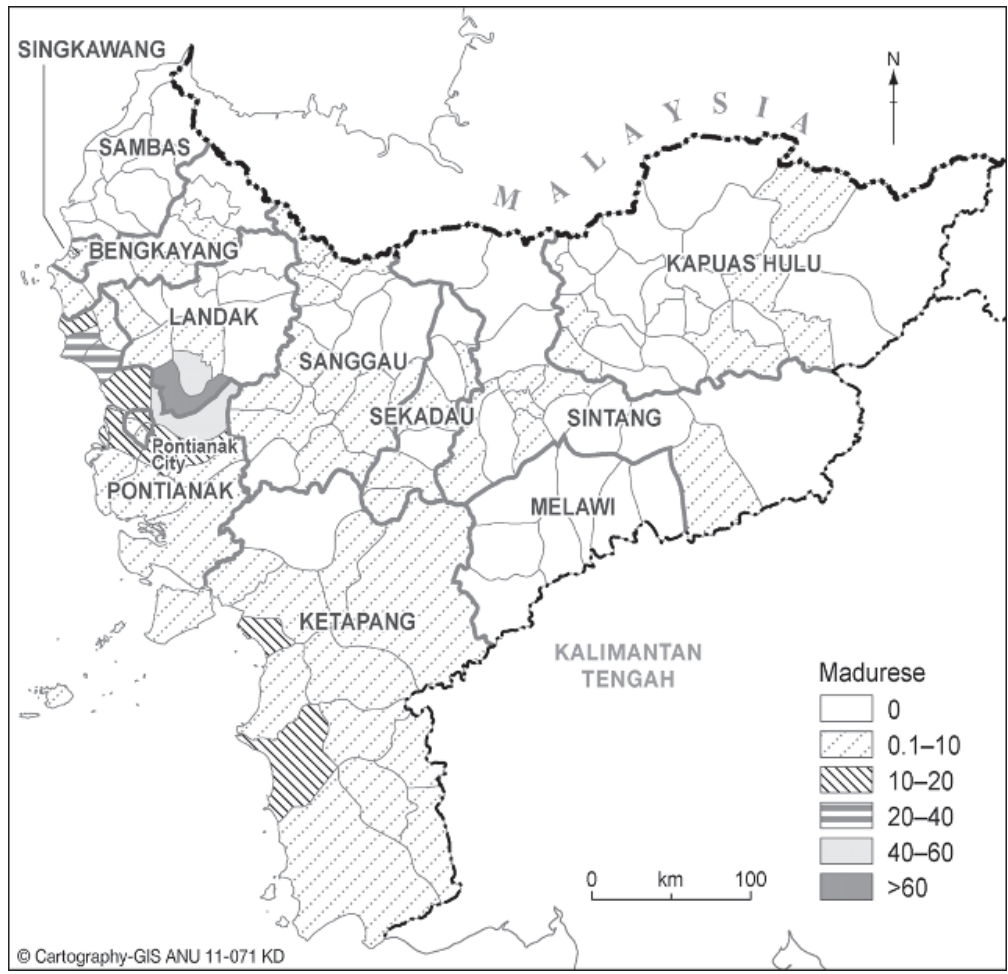

Figure 7.1 Madurese concentration in districts and sub-districts (percentages, 2000)

in 1990 to 4,800 at the end of the $1990 \mathrm{~s} .{ }^{25}$ Given the negative image of the Madurese, their sudden population swell could be perceived as a growing threat to the local, indigenous population. However, attacks on the Madurese in Sanggau were quite obviously a spill over from the core conflict in Pontianak district, as most attacks on the Madurese in the district occurred in its border region with Pontianak district (parts of which have now become Landak district), such as Tayan, Sosok, and

${ }_{25}$ This swell could be partly a result of a Madurese bupati of Sanggau for two terms (1988 to 1998), Colonel Baisoeni Z.A. 


\begin{tabular}{|l|c|c|r|r|r|c|}
\hline \multirow{2}{*}{ District } & \multicolumn{2}{|c|}{1980} & \multicolumn{2}{c|}{1990} & \multicolumn{2}{c|}{ 2000* } \\
\cline { 2 - 7 } & Number & Percentage & Number & Percentage & Number & Percentage \\
\hline Sambas & 23,435 & 3.9 & 32,184 & 4.2 & $10,139 *$ & 1.3 \\
\hline Pontianak & 76,914 & 12.6 & 98,505 & 12.7 & $124,575 * *$ & 13.7 \\
\hline Sanggau & 325 & 0.1 & 427 & 0.1 & 1,483 & 0.3 \\
\hline Ketapang & 16,254 & 6.4 & 9,102 & 2.8 & 19,582 & 4.6 \\
\hline Sintang & - & - & 737 & 0.2 & 286 & 0.1 \\
\hline Kapuas Hulu & - & - & - & - & 52 & 0.0 \\
\hline $\begin{array}{l}\text { Pontianak } \\
\text { City }\end{array}$ & 26,796 & 8.8 & 23,634 & 6.0 & 47,495 & 10.2 \\
\hline Total & 143,724 & 5.8 & 164,589 & 5.1 & 203,612 & 5.5 \\
\hline
\end{tabular}

Table 7.2 Madurese population in West Kalimantan (1980-2000)

*Comprised of 75 persons in Sambas, 2,039 in

Bengkayang, and 8,025 in Singkawang.

**Comprised of 5,994 persons in Landak and 118,581 in Pontianak.

Source: Censuses 1980, 1990, 2000.

Karangan. ${ }^{26}$ No clashes were recorded in Sintang and Kapuas Hulu district although the situation was quite tense there. ${ }^{27}$

One anomaly was the absence of open conflict between the Dayaks and Madurese in Ketapang district despite its large Dayak population and a quite significant number of Madurese settlers (Davidson 2008:13). However, similar to the case of Malay-Madurese disturbances prior to 1999 and Malay-Dayak relations, the absence of open conflict did not mean that relations between them were without problems. A clash between the Dayaks and Madurese occurred in Tumbang Titi in 1994, but this did not develop into an open conflict (Davidson 2008:227; Abas 2002:4). Ethnic tension was reported in some regions in Ketapang during

26 The spread of conflict to non-traditional conflict areas was facilitated by the advance of telecommunications technology, which helped spread news and rumours, and by easy transportation, which helped people's movement and mobilization. A HRW report suggested that the conflict spread to nontraditional conflict areas because Dayaks originally from these areas were wounded by the Madurese in the conflict areas. The report listed 152 Madurese casualties in Sanggau district (Communal violence West Kalimantan 1997:31).

${ }_{27}$ Davidson (2002:230-1) records the presence of Dayak mobs travelling from the far west to Putussibau to look for Madurese. This account should be treated with suspicion since the number of Madurese in Kapuas Hulu was extremely small. If mobs were travelling from the west, why should they 'spare' Sekadau or Sintang towns which had a larger Madurese population? There were no reports of such mobs in Sekadau and Sintang although tension was observed in these regions. 
the 1997 conflict. For instance, Ketapang Dayaks vowed that they would attack the Madurese in Ketapang if the Madurese injured any of their children who were studying in Nyarumkop. ${ }^{28}$ A high level of tension also was evident in Manismata in October 2000 (KR 2001/68). Demographic data comparing Ketapang with the more conflict-prone Sambas and Pontianak districts suggests possible explanations behind the absence of conflicts in Ketapang. One striking difference between the two regions was the steady increase in the numbers of Madurese in Pontianak and Sambas districts, but during the 1980s only a small increase in Madurese population Ketapang. Better economic prospects in Pontianak and Sambas districts, and their close proximity and ease of transportation to the provincial capital were the main attractions for independent migrants like the Madurese. ${ }^{29}$ Compared to Ketapang, these two districts also had better roads that facilitated mobility which was crucial for economic activities. Based on 1996 data, more than half of the province's $423 \mathrm{~km}$ asphalt roads (58 per cent) were located in these districts, compared to Ketapang which only had a share of 11 per cent of road networks (Statistik potensi desa 1997:49). The existing larger Madurese population in Sambas and Pontianak districts also meant better community support for these independent migrants. These large numbers of migrants, who definitely looked for jobs when they arrived, brought more economic competition, a potential cause for tension and conflict. The swelling Madurese population also increased the local population's concern over security.

The size of 'fresh' Madurese migrants in these two districts could have contributed to their relative resistance to adoption of local culture compared with Ketapang Madurese. Closer analysis of the background of the Madurese migrants shows that Pontianak and Sambas districts received a significantly higher number of Madurese migrants from outside

\footnotetext{
${ }_{28}$ Pujaraharja 2004:134-5. Nyarumkop is on the outskirts of Singkawang and near Samalantan, two areas with a large Madurese population.

29 Some indicators consistently support the view that the majority of the Madurese were not participants in government transmigration projects. The settlement pattern of Madurese migrants was one indicator. Sudagung, the first scholar who wrote about Madurese in West Kalimantan, found none of his 400 respondents was a participant of government-sponsored transmigration. Most of his respondents, who lived in Pontianak City, settled in the city when they first arrived, and all of the respondents paid for their own passage to West Kalimantan (Sudagung 2001:91, 94, 110). These conditions were typical of independent migrants, because all government-sponsored migrants would settle in rural areas (certainly not the provincial capital) with all travel expenses and basic needs for several months paid for by the government. A fraction of the Madurese population did participate in transmigration programs. In Sanggau, for example, the majority of its small Madurese population were participants of the plantation-linked transmigration (Arafat 1998:177).
} 


\begin{tabular}{|l|r|r|r|r|r|c|}
\hline Arrival & Sambas & Pontianak & Sanggau & Ketapang & Sintang & $\begin{array}{l}\text { Pontianak } \\
\text { City }\end{array}$ \\
\hline $1986-1990$ & 667 & 1,231 & 0 & 417 & 262 & 2,994 \\
\hline $1981-1985$ & 902 & 1,365 & 66 & 235 & 413 & 1,449 \\
\hline $1971-1980$ & 2,569 & 3,080 & 65 & 287 & 0 & 2,111 \\
\hline $1961-1970$ & 1,455 & 3,007 & 12 & 204 & 0 & 9,26 \\
\hline $1951-1960$ & 718 & 2,502 & 0 & 218 & 0 & 379 \\
\hline $1941-1950$ & 210 & 1,343 & 0 & 201 & 0 & 194 \\
\hline $1931-1940$ & 90 & 405 & 0 & 134 & 0 & 115 \\
\hline $1920-1930$ & 0 & 65 & 0 & 17 & 0 & 31 \\
\hline Before 1920 & 30 & 16 & 0 & & & 0 \\
\hline $\begin{array}{l}\text { Total non WK- } \\
\text { born Madurese }\end{array}$ & 6,641 & 13,014 & 143 & 1,713 & 675 & 8,199 \\
\hline Total Madurese & 32,169 & 98,455 & 427 & 9,102 & 737 & 23,595 \\
\hline
\end{tabular}

Table 7.3 Madurese migrants in West Kalimantan (1900-1990)

Source: Census 1990.

the province, who probably came directly from Madura or East Java. The continuing influx of a large number of Madurese migrants from Madura who brought with them their own original culture reinforced the Madurese cultural practices among the earlier migrant Madurese. This would block or at least slow the process of taking on local culture or habits by the Madurese (Sudagung 2001:104-6). Due to large population numbers and concentrated patterns of settlement, the Madurese had the necessary support to maintain their culture and customs.

A further breakdown of the statistics regarding the origins of Madurese migrants from outside West Kalimantan reveal that Pontianak City and Pontianak district received more migrants from Bangkalan and Sampang, the Madurese western districts. Some scholars, such as Sudagung and Suparlan, claim that these districts were commonly known for their rougher character. On the other hand, Ketapang district received more Madurese from milder regions, such as Pamekasan and Sumenep. ${ }^{30}$ Data on Madurese migration from the 2000 Census substantiated this earlier finding about origins. The census data indicated 
that Pontianak City received almost 73 per cent of its Madurese migrants from Bangkalan and Sampang; Pontianak district received almost 78 per cent; while Ketapang only received 37 per cent. The milder character of the Madurese in Ketapang suggests that they were less 'problematic' and less likely to be involved in conflicts, although further research is needed to examine this possibility.

\begin{tabular}{|c|c|c|c|c|c|c|}
\hline & Pamekasan & Sumenep & Bangkalan & Sampang & $\begin{array}{c}\text { Other East } \\
\text { Java regions }\end{array}$ & Total \\
\hline $\begin{array}{l}\text { Pontianak } \\
\text { City }\end{array}$ & 4 & 73 & 238 & 209 & 92 & 616 \\
\hline Sambas & \multirow{2}{*}{\multicolumn{5}{|c|}{ (no data) }} & 0 \\
\hline Bengkayang & & & & & & 0 \\
\hline Singkawang & & & 5 & 2 & 3 & 10 \\
\hline Pontianak & 7 & 1 & 61 & 116 & 43 & 228 \\
\hline Landak & & & 37 & 3 & 1 & 41 \\
\hline Sanggau & & & 2 & 11 & 7 & 20 \\
\hline Sekadau & & & & & 1 & 1 \\
\hline Sintang & 1 & & & 3 & 7 & 11 \\
\hline Melawi & & 1 & & & 0 & 1 \\
\hline $\begin{array}{l}\text { Kapuas } \\
\text { Hulu }\end{array}$ & & & & & 2 & 2 \\
\hline Ketapang & 8 & 92 & 13 & 83 & 65 & 261 \\
\hline Total & 20 & 167 & 356 & 427 & 221 & 1191 \\
\hline
\end{tabular}

Table 7.4 Origin of Madurese migrants from East Java (1995-2000)

Note: The data exclude Madurese refugees outside

West Kalimantan after the 1999 conflict.

Source: Census 2000.

Another difference between the two regions was the trend toward a much higher concentration of Madurese in rural areas in Pontianak and Sambas districts. The censuses in 1980 and 1990 show that the proportion of Madurese who lived in rural areas in Sambas district had jumped from 74.6 per cent (1980) to 91.1 per cent (1990). For Pontianak district the concentration of Madurese in rural regions had been extremely high, and therefore only recorded a small increase from 98 per cent (1980) to 99.5 per cent (1990). In Ketapang, the condition was quite the opposite. 
In 1980, almost all Madurese in Ketapang lived in rural areas. This number had declined to 96.6 per cent in 1990 and dropped further to 63 per cent in 1995. The declining number of Madurese in rural areas meant that fewer of them would live near Dayaks. A more careful population

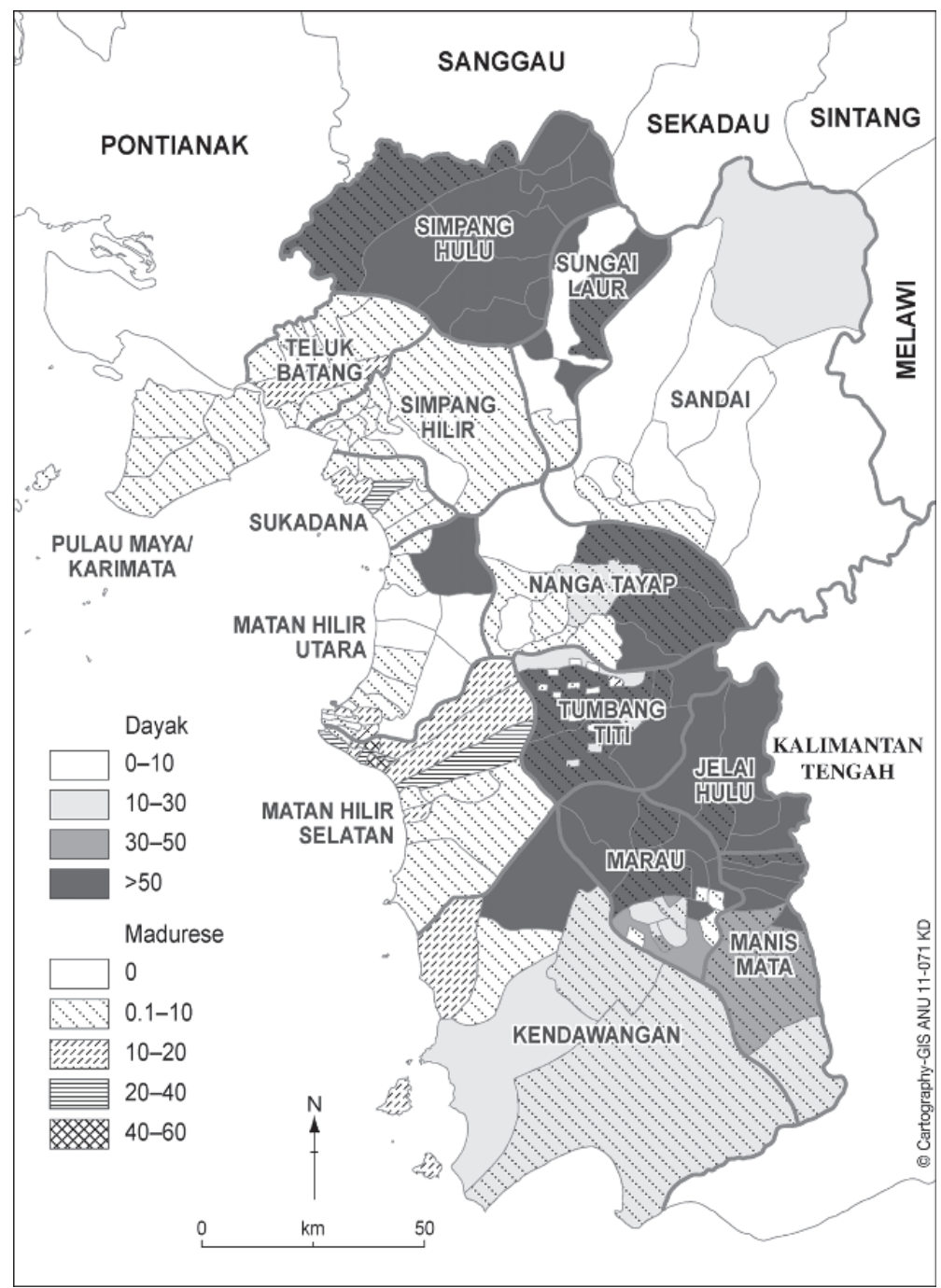

Figure 7.2 Dayak and Madurese population of

Ketapang district (percentages, 2000) 
mapping shows that villages with many Madurese will have only a few Dayaks, and vice versa. The only village in the whole of Ketapang that had significant population of both Madurese and Dayaks was Mulia Baru (Matan Hilir Utara sub-district), a village of 7,055 people. The Madurese proportion in the village was 9.4 per cent, and the Dayaks' was 13.9 per cent.

According to the 1995 population data, Pontianak district had a much higher Madurese concentration at village level than did Ketapang. In 45 out of 162 villages in Pontianak district, the Madurese made up more than 20 per cent of the village population. There were 21 villages with a population of more than 50 per cent Madurese. This was in stark contrast to Ketapang district. Out of 159 villages in Ketapang, only seven villages had a Madurese population of more than 20 per cent. In no villages were Madurese more than 50 per cent of the population. Sambas district was very likely to follow the trend in Pontianak, but unfortunately comparable data for Sambas is not available. More Madurese settling in rural areas in Pontianak (and presumably Sambas) districts implies that there was increasing visibility of the Madurese in Dayak-predominant (rural) areas. Since the Madurese were perceived as a threat by the Dayaks, the higher visibility of the Madurese was seen as an increasing threat.

\begin{tabular}{|l|c|c|}
\hline \multirow{2}{*}{ Madurese population in the village } & \multicolumn{2}{|c|}{ Numbers of villages } \\
\cline { 2 - 3 } & Pontianak* & Ketapang \\
\hline More than 5 per cent & 82 & 25 \\
\hline More than 10 per cent & 53 & 17 \\
\hline More than 20 per cent & 45 & 7 \\
\hline More than 30 per cent & 33 & 3 \\
\hline More than 40 per cent & 27 & 1 \\
\hline More than 50 per cent & 21 & 0 \\
\hline More than 80 per cent & 5 & 0 \\
\hline Total number of villages & 162 & 159 \\
\hline Per cent of Madurese in districts & 18.2 & 4.7 \\
\hline
\end{tabular}

Table 7.5 Madurese population at village level in Pontianak and Ketapang districts (1995)

*Excludes Landak district.

Source: Census 2000. 
The Madurese were known to prefer to settle in a cluster close together. One researcher found that new Madurese migrants tended to open up a new rural settlement for themselves but still within a Madurese area. In the city, new Madurese migrants tended to stay within established settlements (Sudagung 2001:104-6). Unfortunately, no specific studies of the Madurese settlement trends in the conflict regions have been done. Statistical data available at village level produced by the 2000 census could not report the condition of Madurese settlement in Sambas and in most parts of Bengkayang and Landak districts, because Madurese no longer lived there after the 1999 conflict. One way to assess the Madurese settlement trends in Sambas and Bengkayang districts is by mirroring the trend of Madurese settlements in the neighbouring Pontianak district. ${ }^{31}$ Table 7.5 shows that almost a third of villages in Pontianak district had more than 20 percent Madurese in their population, and 21 villages with a Madurese population of more than 50 per cent.

High Madurese population concentrations could still be observed in some areas of Landak that were spared or lightly affected by violence such as in Sebangki sub-district. There, concentrations of Madurese were very high, particularly in Sei Segak village (91.4 per cent of the village population) and in Rantau Panjang (88.2 per cent). On the other hand, Bengkayang district no longer had a Madurese concentration as high as in the mid-1990s. Samalantan and Sanggau Ledo sub-districts, which had high concentrations of Madurese prior to conflict, had only thirteen and nineteen Madurese in the whole sub-districts respectively, based on the 2000 census. This differed greatly with the population figures prior to the conflict, when Samalantan was estimated to have at least 8,091 Madurese and Sanggau Ledo at least 3,102 (Arafat 1998:15-6). Many villages in Samalantan had been estimated to have from 40 percent to more than 80 percent Madurese population. Within Bengkayang the only sub-district that still had a significant Madurese concentration in 2000 was the coastal Sei Raya. There, the villages of Sungai Duri had 12.9 per cent Madurese, Sungai Jaga A had 9.3 per

$3^{1} \quad$ Pontianak district had largely escaped the conflict so there was no significant permanent out-migration of Madurese. Therefore the data on the Madurese population in 1995 in the district, as captured through census 2000, was reliable. Pontianak district is a good mirror because it is geographically linked to the conflict-prone districts - Bengkayang, Landak and Sambas. It also shares some similarities with those districts, as discussed previously: an extensive road network, large Madurese population, and the trend of the Madurese to settle in rural areas. 


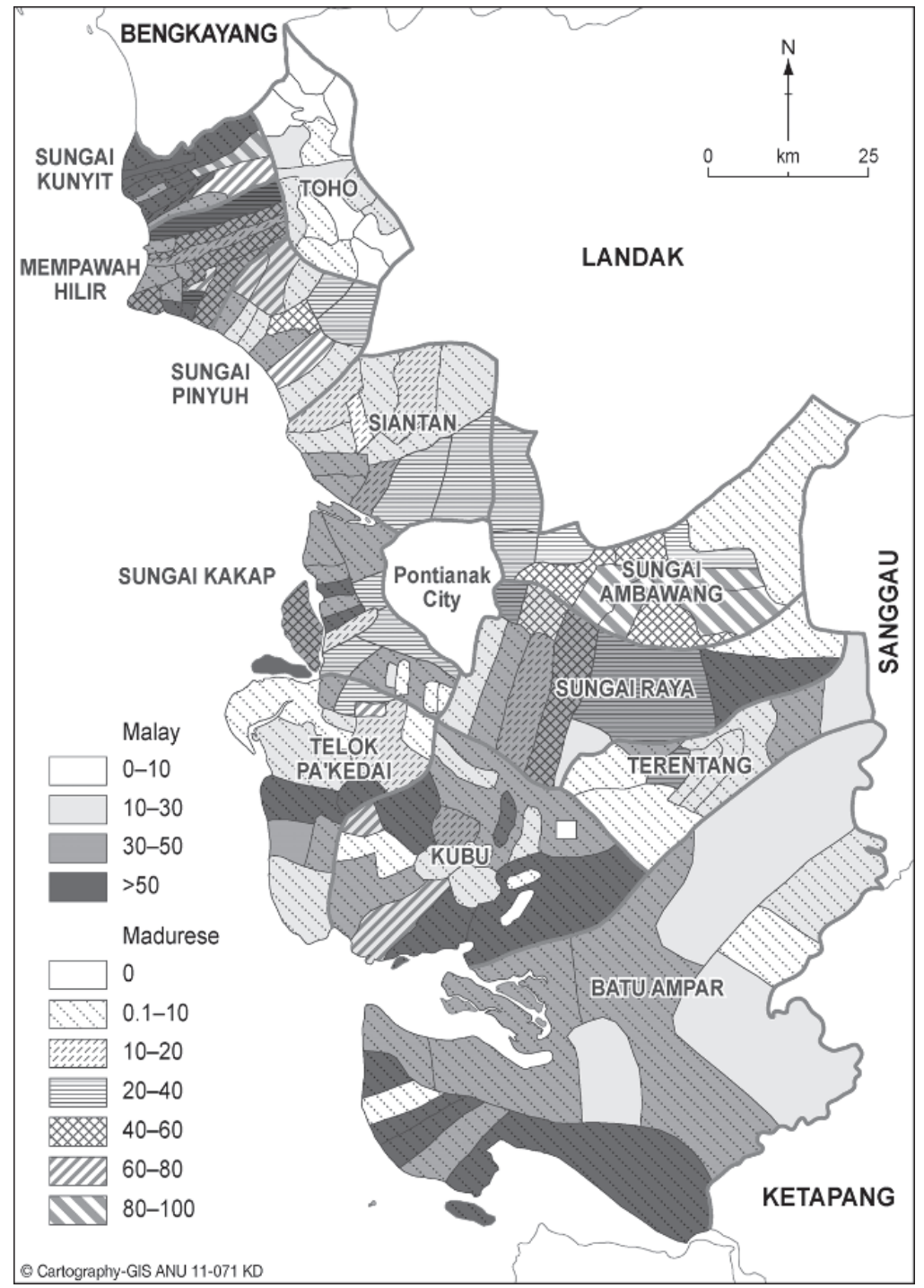

Figure 7.3 Malay and Madurese population of

Pontianak district villages (percentages, 2000) 
cent and Karimunting had 8.1 per cent, while Sei Pangkalan II only had 2.4 per cent.

The 'Madurarization' of a village or neighbourhood began with settlement of some Madurese in the area. As the number of Madurese settlers grew, occupants from other ethnic groups, who felt anxious living close to Madurese neighbours, sold land or property rather cheaply to incoming Madurese and resettled elsewhere. ${ }^{32}$ Therefore almost all Madurese 'villages' were formed through piecemeal land acquisition unlike many Javanese villages, which were formed almost instantly through transmigration projects. ${ }^{33}$ An example is that of Salatiga village (Landak), a place where many Madurese were killed during the 1997 conflict. A Dayak researcher notes that prior to 1997, the Salatiga area had 1,200 Madurese and only about 200 Dayaks. Dayaks lived in Salatiga for a short time after the Chinese were ejected from the village following the 1967 conflict, but they gradually retreated from central Salatiga when the Madurese started to settle in the village. One reason for this retreat was the Dayak fear of the Madurese and their desire to avoid dealing with them (Giring 2003:27, 31, 67-72). The non-Madurese newcomers chose to live in non-Madurese quarters. As a consequence, the village could virtually be divided into two quarters: a quarter with a high concentration of Madurese, and a multi-ethnic non-Madurese quarter (Giring 2003:137). A Malay researcher found a similar trend in Sari Makmur village in Tebas sub-district (Sambas). Formerly, it had been a 99 percent Malay village, but it later became a Madurese village because the majority of the Malays moved out from the neighbourhood. They could not live with the Madurese who tended to intimidate and resort to violence, particularly when it came to landownership and land boundaries (Abas 2002:82). This explained why there were many Madurese villages, although the majority of them did not participate

$3^{2}$ The flight phenomena are recorded elsewhere. In the US in the not-so-distant past, a 'white' neighbourhood could slowly turn into a 'Black' one after the white population felt that the Blacks moving into the neighbourhood would bring the property prices down, increase the crime rate, and have other negative consequences. The 'white flight' would leave behind a predominantly Black community (Laitin 1998:21; Seitles 1996).

33 This piecemeal acquisition had perhaps led to land disputes which in turn created the persistent stereotype that the Madurese liked to encroach on land belonging to others (menyerobot tanah). 
in government transmigration. ${ }^{34}$ This high population concentration tended to prevent more meaningful interactions and better understanding between Madurese and other ethnic groups.

\section{ECONOMIC AND POLITICAL ROLE OF THE MADURESE}

Some have speculated that Madurese habit of social domination might have created the economic jealousy that became the underlying factor in the 1998 conflict. So far no studies have focussed on the role of the Madurese in the West Kalimantan economy. Indications derived from the census do not show a high degree of Madurese dominance in the economy. The 1990 census shows that the majority of the Madurese in Sambas, Pontianak, and Ketapang worked in agricultural-related sectors, but their share in the total workforce in these sectors was lower than that of other major ethnic groups. In Sambas district, 48.7 per cent of all Madurese workers worked in agriculture-related occupations, but their share in these occupations was less than 8 percent - an insignificant percentage compared to the share of the Malays, Dayaks, and Chinese. In Pontianak district, the proportion of Madurese who worked in agriculture-related employment was generally two to three times higher than the share of the Madurese in Sambas, but still relatively low compared to the shares held of other ethnic groups. Local people also widely believed that Madurese tended to dominate in difficult job sectors, such as road construction and logging transportation. The statistics, however, show that the share of other ethnic groups in these sectors was not small either. In Sambas, for example, the Madurese had a 35 per cent share of bricklaying, stonemasonry and tiling, while Malays and Chinese had 34 per cent and 22 per cent shares respectively. Madurese were not justifiably the focus of native economic jealousy and certainly did not dominate the regional economy.

However, the Madurese did have disproportionate shares in specific occupations in certain districts. According to the 1990 census Madurese

34 Saad (2003:51) mentions several Madurese concentrations in Sambas: Sei Nilam, Sei Nyirih and Matang Tarap (Jawai sub-district), Rambayan, Serang, Sempadung, and Puting Beliung (Tebas subdistrict), Rambi and Senangi (Sambas sub-district), Kota lama (Teluk Keramat sub-district), and Sebubus (Paloh sub-district). Within Bengkayang district, Arafat (1998:15-6) notes large Madurese concentration in Samalantan sub-districts, particularly in villages of Marga Mulia, Sendoreng, Jirak, Mendung Terusan, Monterado, Sungai Petai, and Kincir. Some concentration of Madurese could also be found in villages of Merabu, Jawa, Sanggau Kota, and Kandasan in Sanggau Ledo sub-district. 
were dominant as tricycle (becak) drivers in Pontianak City: having an 83 per cent share of the city's total of 2,913 tricycle drivers. ${ }^{35}$ Their share in 1982 was only 71 per cent (Sudagung 2001:84-6, 96). In Sambas district, about 54 per cent of 1,033 livestock workers were Madurese. There, their share among the tricycle drivers was only about 31 per cent. In Ketapang, about 66 per cent of the total 645 livestock workers were Madurese. In Pontianak district, the main occupations of the Madurese were logging (42 per cent) and forestry - 'orchard and related tree and shrub crop' work (37 per cent). Their domination could also be found in more specific areas, such as traditional markets. Davidson found that Madurese had a significant share as traders in traditional markets in Pontianak City. From four traditional markets in the city, the share of the Madurese was 47 per cent, competing closely with the Malays at 53 per cent (Davidson 2008:165). Although recent statistics are not available, the Madurese share in these sectors seemed to have increased in years leading up to conflict due to their persistence and aggressive business practice and the reluctance of their competitors to block Madurese entrance into these fields so as to avoid confrontations.

Although this domination was sectoral and relatively small, it was still a potential source of tension. Some sectoral domination was secured by the Madurese at the expense of other ethnic groups. Involuntary retreat could stir up ill feeling toward the Madurese. ${ }^{36}$ Sudagung's research shows that in Pontianak City, the growing numbers of Madurese tricycle drivers and boat operators displaced Malays, who had been dominant in these two areas. ${ }^{37}$ The potential for conflict was higher if the sector involved direct marketing to customers, as the Madurese were known to

35 Their share in other occupations thought to be Madurese-dominated such as 'other' transport operators (very likely to be sampan or boat operators) was only 29 per cent and motor vehicle drivers (most likely to be oplet or mini-bus drivers) only 15 per cent. However, these figures might have jumped by 2000 , although data was not yet available.

$3^{6}$ This sectoral domination was not necessarily problematic. Madurese domination in livestock raising, for example, was not a threat to the Dayaks, as they raised different stock. The Dayaks mainly raised pigs, while the Madurese raised cattle. These stocks were transported along different trade routes, to different abattoirs and outlets, and to quite separate consumers.

37 In his research on the Madurese economic role, Sudagung observed there were potential conflicts between the Madurese and Malays in Pontianak, as the latter had been pushed out from certain occupations such as tricycle drivers and boat operators. The share of Madurese working as boat operators had also increased to 69 percent in 1980, while the Malays' share was reduced to only 31 per cent. He observed the new trend of an increasing number of Madurese mini-bus drivers from 1978-80 in Pontianak, and envisaged that one day the Madurese could dominate this occupation too (Sudagung 2001:84-6, 96,134-7). 
be blunt and rough in their business dealings with both customers and competitors. ${ }^{38}$

The wealth of the Madurese in Sambas and other conflict-affected areas remains to be documented. If landownership is a good indicator of the fact that Madurese the majority of Madurese worked in agriculture, and thus and could be considered to have had good economic standing but they still could not have been considered very wealthy. According to the 1980 census, about 48 per cent of the Madurese in Sambas owned less than two hectares of land. As a comparison about 46 per cent of the Dayaks owned between two and three hectares of farmland referenced in the same period. The average size of Madurese land ownership did not change much in the next 20 years. Based on data supplied by 4,098 Sambas refugees in 1999, on average Sambas Madurese landowners owned about 1.1 hectares of land. ${ }^{39}$ This size of farm plot was not considered high as it was less than the minimum two hectares of land owned by those who participated in transmigration. As in other places, a few Madurese always became extremely successful and wealthy, but this was not the norm.

The evidence above tends to support the arguments that it was not the Madurese domination or wealth per se that had become the problem for the original population. Compared to the Madurese, Chinese economic domination was significantly more visible and a natural source of economic jealousy for the Dayaks or Malays. The Javanese transmigrants, who had received much support from the government, also should have become the object of local jealousy. In line with the ethnic argument noted previously, it was their rough conduct in their economic interaction that was problematic. Sudagung gave the example of Madurese boat operators in Pontianak City. He observed that when clients agreed to take a boat from a Madurese boat operator they would not usually change their decision. If they did, they would receive verbal abuse from the operator (Sudagung 2001:126). Locals will readily give more examples of Madurese economic wrong-doing and misconduct. The contribution and influence of the Madurese to local politics was negligible.

\footnotetext{
$3^{8}$ In the past, direct competition between the Madurese and the Dayaks or the Malays in marketing agricultural produce was unlikely because it was handled mostly by Chinese middlemen. Farmers selling their produce directly to consumers in the market is a rather new trend, which only started at the end of 1990s.

39 Aminah 2002:Appendix 10. Although similar land data for Bengkayang district is not available, the trend was very likely similar to that in Sambas because of their geographical proximity.
} 
7 Ethnic conflict and politics

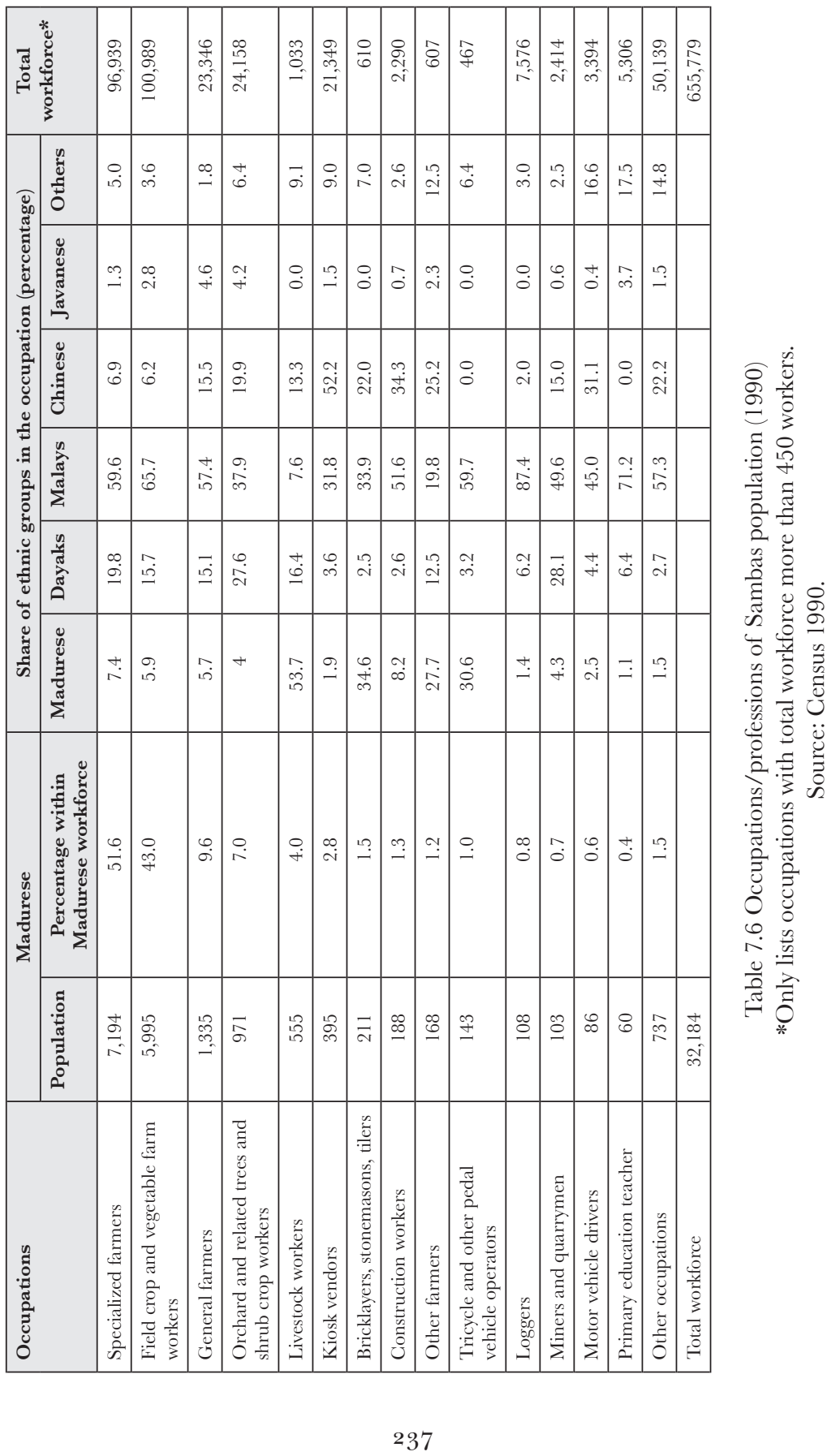


Most Madurese were sympathizers of the PPP, a party that secured only a few seats in the district and provincial level. ${ }^{40}$ PPP continued to lose votes in the province following the 1977 election. PPP only experienced a slight increase at the provincial level and in Sintang, Kapuas Hulu and Ketapang districts in the 1992 election. The decreasing PPP share in the district or provincial DPRD meant that opportunities for Madurese politicians to become PPP legislators were minimal. Most important leaders of PPP at the provincial level as well as its legislative representatives were Malays. If there were Madurese representatives of PPP at district level, their numbers were likely to be insignificant.

\begin{tabular}{|l|r|r|r|r|r|}
\hline District & $\mathbf{1 9 7 7}$ & $\mathbf{1 9 8 2}$ & $\mathbf{1 9 8 7}$ & $\mathbf{1 9 9 2}$ & $\mathbf{1 9 9 7}$ \\
\hline Pontianak City & 38.9 & 29.8 & 24.8 & 21.9 & 28.9 \\
\hline Pontianak & 27.4 & 26.8 & 21.7 & 20.6 & 19.6 \\
\hline Sambas & 33.1 & 28.4 & 18.2 & 15.5 & 17.2 \\
\hline Sanggau & 5.8 & 5.6 & 5.6 & 5.2 & 5.2 \\
\hline Sintang & 6.3 & 9.1 & 6.4 & 8.8 & 7.2 \\
\hline Kapuas Hulu & 12.1 & 10 & 6.2 & 7.9 & 10.5 \\
\hline Ketapang & 16.3 & 20.4 & 15.9 & 16.5 & 15.5 \\
\hline Province & 21.9 & 20.7 & 15.5 & 14.7 & 15.3 \\
\hline
\end{tabular}

Table 7.7 PPP performance in the 1977, 1982, 1987, 1992, 1997 elections (percentages)

Source: Various government reports.

There was also no evidence of a significant Madurese rise in the bureaucracy which might concern the Malays or the Dayaks. Their low educational attainment limited Madurese chances to work for the bureaucracy. The 2000 census noted that about 65 per cent of Madurese in the province did not attend or did not finish elementary school, and only 0.4 per cent of them had obtained a university degree. Their educa-

$4^{\circ}$ Roekaerts estimated that the West Kalimantan Madurese support for PPP was 100 per cent (1985:22). Their strong association to PPP was easy to verify if one checked the voting behaviour of the Madurese in Madura. All districts in Madura were strongholds of PPP. In Sampang district, for example, PPP even won in the 1982 and 1987 elections. In 1982, PPP won 23 seats, while Golkar won only 9; in 1987 PPP had 20 seats while Golkar had 16 seats (Soetrisno et al. 1998:209). 
tional achievement was the worst compared to other major ethnic groups in the province. ${ }^{41}$ As has been discussed previously, for the Dayaks, the main obstacles were the Malays or the Javanese who had dominated the bureaucracy, and not the Madurese. The main obstacles for the Malays to climb the bureaucratic ladder were the Javanese and, to a lesser extent, the Dayaks.

\begin{tabular}{|l|c|c|c|c|c|c|c|c|}
\hline $\begin{array}{l}\text { Education } \\
\text { level }\end{array}$ & Chinese & Malays & Javanese & Madurese & Bugis & Dayaks & Others & Average \\
\hline $\begin{array}{l}\text { No } \\
\text { schooling }\end{array}$ & 43.8 & 45.0 & 32.9 & 65.2 & 46.8 & 56.3 & 40.0 & 47.8 \\
\hline $\begin{array}{l}\text { Elementary } \\
\text { school }\end{array}$ & 29.3 & 29.5 & 30.4 & 23.7 & 27.8 & 27.4 & 27.5 & 28.5 \\
\hline $\begin{array}{l}\text { Junior high } \\
\text { school }\end{array}$ & 14.2 & 12.1 & 14.9 & 6.8 & 12.1 & 9.6 & 12.5 & 11.6 \\
\hline $\begin{array}{l}\text { Senior high } \\
\text { school }\end{array}$ & 11.2 & 11.7 & 18.2 & 3.8 & 11.6 & 5.9 & 16.0 & 10.5 \\
\hline $\begin{array}{l}\text { Academy/ } \\
\text { university }\end{array}$ & 1.4 & 1.7 & 3.6 & 0.4 & 1.6 & 0.7 & 3.9 & 1.6 \\
\hline Others & 0.0 & 0.0 & 0.1 & 0.0 & 0.0 & 0.0 & 0.0 & 0.0 \\
\hline Total & 100 & 100 & 100 & 100 & 100 & 100 & 100 & 100 \\
\hline
\end{tabular}

Table 7.8 Ethnic education levels in West Kalimantan (2000 percentages)

Source: Census 2000.

\section{ROLE OF NATIONAL ECONOMIC CRISIS}

Although ethnic-related factors played an important part in the majority of conflicts in this province, the unstable political and economic condition faced by the nation at the end of the 1990s also contributed to the 1997 and 1999 conflicts.

The economic crisis which hit Indonesia in 1997 significantly increased the level of poverty in Indonesia. Prior to the crisis, the poverty level in Indonesia had been in decline. UNDP reported that the Indonesian poverty rate was reduced to 11.8 per cent of the total population by 1996. The economic crisis reversed the trend and bounced the

$4^{1} \quad$ Schooling, a venue for socialization and cross-cultural exchanges between the youth from different ethnic background, was lacking among the Madurese. This deficiency indirectly contributed to the conflict (Tim Pencari Fakta DPR 1999:20). 
poverty rate back to 23.5 per cent in $1998 / 1999 .{ }^{42}$ The poverty rate in West Kalimantan in 1996 before the crisis hit was almost 22 per cent, the worst in the nation after Irian Jaya and East Timor. Numbers of the poor in the province multiplied because of the crisis, and in 2000 poverty in West Kalimantan still hovered around 29 per cent, the fifth poorest in the nation. ${ }^{43}$ Only a small portion of the populace who lived near the border with Malaysia benefited from the economic crisis because of their cross-border businesses and higher exchange rates (Akcaya, 22-3-1999). The economic crisis multiplied the numbers of the desperately poor who were highly susceptible to demagoguery and to bursts of violence stemming from frustration and social problems, such as crimes and conflicts. ${ }^{44}$

The economic crisis considerably weakened the New Order regime's legitimacy and its ability to control the country. Political opponents and university students used the crisis to intensify their criticism of the regime. As street demonstrations led by university students became more frequent, social violence also increased dramatically from eight and fifteen incidents for 1996 and 1997 to 124 in 1998. Deaths associated with the incidents indicated the severity of the conflicts; they jumped from 117 deaths in 1996 and 131 in 1997 to 1,343 in $1998 .{ }^{45}$

When Soeharto finally resigned as president on 21 May 1998, Jakarta and some other parts of the country had fallen into chaos. The demise of the authoritarian regime and the installation of a democratic regime saw the unleashing of social and political movements at unprecedented levels. In West Kalimantan political reforms and decentralization initiatives stirred up political dynamics, some of which included mass mobilization that resulted in violence. ${ }^{46}$ One source recorded at least 29 violent conflicts between the fall of the New Order and the conflict in Sambas in 1999 (Agustino 2005:83-92).

The news of violent conflicts, the almost daily student demonstrations, and the tense political situation at the national level, reached the West Kalimantan population without as much filtering as in the past.

$4^{2} \quad$ See http://www.undp.or.id/general/ (accessed 25-6-2005).

43 See http://bankdata.depkes.go.id/Profil/ (accessed 12-5-2005).

44 Poverty and conflict are closely related although poverty does not necessarily result in conflict (Lichbach 1989:465). When poverty gives rise to frustration and despair, it can be a cause of conflict (Grandvoinnet and Schneider 1998:20).

45 The author when making the tabulation understood that freedom of information before 1998 could influence the number of reported incidents. Therefore the number of incidents before 1998 could be much higher in reality (Tadjoeddin 2002:35).

$4^{6} \quad$ Mansfield and Synder (1995) argue that sudden democratization is linked to increasing conflict. 
The freer press and private television stations had brought these conflicts closer to home and radicalized some in the community. ${ }^{47}$ Repeated conflicts can be then accepted as a common or normal occurrences or even the right thing to do, particularly if the conflict is perceived as being justified, for example, defending one's religion, fighting the oppression or aggression, or seeking independence.

Crisis is important but not necessary for ethnic conflicts to develop. Majority ethnic conflicts between the Dayaks and the Madurese in West Kalimantan had occurred during relative stability in the 1970s and 1980s. Crisis and radicalization also does not always lead to conflict. Despite tense atmosphere the greater part of Indonesia remained peaceful during the crisis. Crisis however has potential to intensify conflict when it happens was as the case of the conflict in 1997 and 1999 in West Kalimantan. Serious ethnic conflict needs underlying or perennial factors, which in the case of conflicts in West Kalimantan, was the strained ethnic relations between the conflicting parties. These issues had created a high level of hostility and distrust, which could easily transform any small fracas or petty crimes into open ethnic conflicts. In the past the strained relations was 'maintained' under the watchful eye of the repressive regime. However, they burst into the open after the collapse of the New Order. The crisis and existing problems are two good combinations for a serious ethnic conflict to develop; what it needs is a spark to trigger the conflict.

\section{POLITICAL MOTIVATIONS BEHIND THE CONFLICTS}

Ethnic conflicts in West Kalimantan were often linked to the wider national political agenda. Ample political motives existed among the marginalized Dayak elite. However no evidence links the conflicts with political manoeuvres or events, at least none were discernible at the start of the conflicts. Both conflicts in 1997 and 1999 started from street fights

47 Watching violent TV shows, for example, has been linked with the increased violent behaviour of the viewers (Huesmann, Moise and Podolski 1997:184; Siegel 2003:159). By this time Indonesia already had at least five private television stations in operation. The first private television station, RCTI, was established in 1987, followed by SCTV (1989), TPI (1990), ANTV (1993), and Indosiar (1995). On their history and also role in the democratization in Indonesia, see Sen (2002:82-4). Although they were required to broadcast heavily filtered news produced by TVRI, the state television station, they were allowed to produce their own soft news, which usually gave more information to the audience (Fakarta Post, 13-2-2000). After the reform in 1998, private broadcasting stations had slowly evaded the requirement to relay the news produced by TVRI. The new law on broadcasting in 2002 (Law 32/2002, particularly article 40) no longer mentioned the requirement of private stations to relay the news produced by TVRI. 
or arguments between individuals of opposing ethnic groups. These two conflicts had a very different nature from 'political' conflicts such as election-related conflicts in Banjarmasin or Sampang in May 1997, or clashes between PDI supporters and government-backed attackers during the take-over of the PDI headquarters in July $1996 .{ }^{48}$

Political events, such as the election of a governor or a district head, or a general election have potential as triggers to conflict. Political rivalries between the candidates, for example, can lead to street fighting among their supporters. Disappointed candidates who lost a contest can stir up trouble through their supporters. However, such events between 1996 and 1998 in the province ended peacefully, and no evidence links them to the 1997 conflict. The district head election in Sambas was concluded in June 1996, at least six months before the conflict. Another district head election in Ketapang, the tranquil southernmost district in the province, concluded in February 1998 without any incidents. ${ }^{49}$ Other district elections were not due until the middle of 1998. The general election in mid-1997 in the province also ended without major incidents. PDI which had become a potential source of instability (or conflict) due to popular opposition to its pro-regime leadership did not face significant opposition in the province. While it obtained 6 percent fewer votes compared to the previous election, its performance in the province was exceptionally good compared to its result at the national level. Votes for PPP, another party, had slightly increased. Golkar won quite comfortably in the province, gaining about 70 per cent of the votes. ${ }^{50}$

Unlike the conflict in 1997, the 1999 violence was surrounded by several national and local political events that made it a politically-

$4^{8}$ Soetrisno et al. (1998:319) grouped these two clashes together with the other four as political conflicts, while conflict in 1997 in West Kalimantan was treated as ethnic conflict.

49 In the election in Sambas, the strongest contenders were the incumbent district head Syafei Djamil and local military chief Tarya Aryanto, who were both active military officers. Despite strong local support, Djamil did not take part in the competition apparently after he failed to obtain the required approval from the military. Aryanto finally won the election, while Djamil returned to army headquarters in Jakarta. Some tension was apparent during the nomination of the candidates, but post-election conditions were peaceful as in most elections during the New Order regime (Akcaya, January-March 1996). In an election in Ketapang, civilian Morkes Effendi, who was nominated by the regime to head the district, was elected as district head on 17 February 1998 without any election troubles (Akcaya, 18-2-1998).

$5^{\circ} \quad$ At the provincial level PDI gained 15.4 per cent of votes in 1997, compared to 21.6 per cent in the previous election. This was still much better than its national performance. At national level, PDI obtained only 3 per cent of votes in the 1997 election, a significant drop from the previous election of 14.9 per cent of votes. For the result of these three political parties at national election from 1971 to 1997, see Haris 2004:31. 


\begin{tabular}{|l|c|c|c|}
\hline Election year & PPP & Golkar & PDI \\
\hline 1971 & 18.5 & 66.6 & 14.7 \\
\hline 1977 & 21.9 & 68.8 & 9.3 \\
\hline 1982 & 21.0 & 70.7 & 8.3 \\
\hline 1987 & 15.5 & 68.7 & 15.7 \\
\hline 1992 & 14.7 & 63.6 & 21.6 \\
\hline 1997 & 15.3 & 69.4 & 15.4 \\
\hline
\end{tabular}

Table 7.9 Political parties and elections in West Kalimantan (1971-1997 percentages)

Source: Various government reports.

driven conflict. The fall of the New Order regime, the installation of a democratic regime and the introduction of decentralization policies had certainly given new manoeuvring ground for local political elite and commoners. In particular, the rise of Dayak political lobbies and their success in securing two district head positions at the expense of Malays might have drawn retaliation from the Malays in the form of conflict. One scholar even claims that the intended target of the Malays in the 1999 conflict were the Dayaks. ${ }^{51}$

In search of possible political explanations behind the conflicts in the province, one needs to examine those who would have benefitted from the conflict. The military is the prime candidate because its involvement in conflicts is not new to Indonesia. In the past, the military has instigated conflicts to crush their political opponents - for example, those against the Communists in Java and Bali between 1965 and 1966. As noted previously, they were accused of inciting the massacre of the Chinese in West Kalimantan in 1967. The rivalries between the topranking officials at the national level on several occasions have led to proxy-conflicts at the grass-roots level. ${ }^{52}$

The new rationale for military involvement in the conflicts at the end of the 1990s was related to their waning political role at the national and regional level. Those who envisaged the military involvement in the

$5^{1}$ Davidson 2008:136. I found the Davidson assessment was inaccurate; at least there were no political intentions at the start of the conflict, as I will make clear in the last section of this chapter.

$5^{2} \quad$ Rinakit (2005:52), for example, concluded that several important incidents during New Order Indonesia were the result of competition among top army generals. 
conflict argued that the conflicts would force the government to reinstate or even increase the military role to keep order in the country. The state would also allocate more financial support to the army's increased activities. ${ }^{53}$ One indication of their diminishing role was the decline in the number of military officers appointed to certain important positions. One source found that between 1977 and early 1990 the proportion of ministers with military background had declined from 42.5 per cent to 24 per cent, the military ambassadors had also declined from 41 per cent to 17 per cent, and the military governors from 70.3 per cent to 40 per cent (Rinakit 2005:45). The percentage of military governors further dropped from 54 per cent (1992-1996) to 39 per cent (1997-2001). At the district head level, the percentage dropped from 47 per cent to 12 per cent for the same period (Malley 2003:113-4). The trend continued after the fall of the New Order as the military was pressured to withdraw from its political role. The military was allocated fewer seats in the DPR after the 1999 election, and accepted that their representation in the legislature would be abolished by 2004. It agreed to disclose and make transparent all appointments of retired military officers to civilian posts, and agreed that no active military officers would be able to assume any civilian positions in the government (Lee 2000:699-700). Following the trend at national level, military control over the politics and bureaucracy of West Kalimantan also declined. The position of governor which had been reserved for a military person since 1966 was returned to a civilian in 2003. Some district head positions had been gradually returned to civilians during the 1980s. All military district heads who were elected during the New Order were replaced by civilians after their term ended at the end of the 1990s or early in the 2000s.

The easiest and most common indications employed by proponents of the 'military involvement' argument is the slow or misguided responses of security forces during the conflict (Communal violence West Kalimantan 1997). However, the slow response could be due to other legitimate reasons such as understaffing, fear of large and aggressive mobs, and concern about

53 Davidson 2008:99-100; Van Dijk 2001:394-5; Arafat 1998:267-8. There were still other arguments for the military involvement in the conflict. For example, from the financial side the conflicts could generate significant side income for the military, which was important for financing its large structure and underpaid personnel. In conflict-torn areas where peace had not been fully restored, the military would keep receiving orders to protect business and industrial complexes or to escort businessmen or individuals who needed to travel through conflict-affected areas. All of these security services were highly prized and became sources of income for the military (Azca et al. 2004:35-6). 


\begin{tabular}{|c|c|c|c|c|c|c|c|}
\hline Background & $1967 / 8$ & $1973 / 4$ & $1978 / 9$ & $1983 / 4$ & $1987 / 8$ & $1993 / 4$ & $1997 / 8$ \\
\hline Military & 5 & 5 & 6 & 5 & 4 & 3 & 3 \\
\hline Givilian & 2 & 2 & 1 & 2 & 3 & 4 & 4 \\
\hline \multirow{6}{*}{$\begin{array}{l}\text { Military } \\
\text { district heads }\end{array}$} & $\begin{array}{l}\text { Pontianak } \\
\text { City }\end{array}$ & $\begin{array}{l}\text { Pontianak } \\
\text { City }\end{array}$ & $\begin{array}{l}\text { Pontianak } \\
\text { City }\end{array}$ & $\begin{array}{l}\text { Pontianak } \\
\text { City }\end{array}$ & $\begin{array}{l}\text { Pontianak } \\
\text { City }\end{array}$ & $\begin{array}{l}\text { Pontianak } \\
\text { City }\end{array}$ & $\begin{array}{l}\text { Pontianak } \\
\text { City }\end{array}$ \\
\hline & Sambas & Sambas & Sambas & Sambas & Sambas & Sambas & Sambas \\
\hline & Sanggau & Sanggau & Sanggau & Sanggau & Sanggau & Sanggau & Sanggau \\
\hline & Pontianak & Pontianak & Pontianak & Sintang & Sintang & & \\
\hline & Ketapang & Ketapang & Ketapang & Ketapang & & & \\
\hline & & Sintang & $\begin{array}{l}\text { Kapuas } \\
\text { Hulu }\end{array}$ & & & & \\
\hline
\end{tabular}

Table 7.10 Military and civilian district heads in West Kalimantan Source: Various government reports.

human rights violation (Communal violence West Kalimantan 1997). The tardy anticipation of conflict on the part of the security forces could be also due to the collapse of its intelligence network. ${ }^{54}$ In reality, the military was never totally immobile and passive in the case of conflicts in 1997 and 1999 in West Kalimantan. HRW mentioned the efforts of the military to evacuate refugees, and that on some occasions they had to shoot at the mobs who defied orders or who tried to attack those under military protection. ${ }^{55}$ In order to prevent the spread of conflict, the military issued a night-time curfew on 2 January 1997 and blocked road access to Sanggau Ledo (Petebang 1998:85). The 1999 conflict chronology above also showed that the military had taken similar preventive and repressive actions, including shooting at the Malay crowds who were suspected of planning attacks on the Madurese refugees.

Conflicts could be used as a pretext by the military to restore kodam or Regional Military Command (Davidson 2002:315). The plan to restore kodam had been proposed in May 1998, a few days before the fall of the New Order regime, and the eruption of disturbances should

54 The military defended their delicate handling of the conflict because they did not want to be accused of violating human rights (Van Dijk 2001:393-4).

55 Communal violence West Kalimantan 1997. The National Human Rights Commission (Komnas HAM) set up by the government considered these repressive acts (the shootings) necessary as the security officers needed to defend their lives and to safeguard order and peace (Akcaya, 16-2-1997). 
have given more justification for such restoration. ${ }^{56}$ The 1999 conflict in West Kalimantan sparked the restoration debate in the province between March and December 1999. No less than a member of the National Human Rights Commission (Komnas HAM), who had to deal with the misconduct of military personnel, supported the restoration of the kodam in West Kalimantan. Some believed that the establishment of kodam in the province would result in quicker security responses if conflicts occurred in this region (Akcaya, 30-3-1999). However, the argument that the military used the conflicts to speed up restoration in the province was less credible in West Kalimantan as the highest military commander in the province himself rejected the idea of restoring the kodam in the province (KR 2003/98). And so far, there has been no kodam exclusively for West Kalimantan, although at least two have been restored elsewhere. ${ }^{57}$

The next focus is the conspiracy theories that believed that the conflicts were part of a grand scheme to destabilize the country in order to achieve certain political agendas and goals. Some, such as the leader of the NU (Nahdlatul Ulama, the largest Muslim organization in the country) Abdurrahman Wahid, believed that many conflicts in the region were triggered by those who were still loyal to former President Soeharto. ${ }^{58} \mathrm{He}$ also believed that there was a 'Green Dragon Operation', a conspiracy to destabilize NU, as many initial conflicts occurred in Java, in NU strongholds (Eklöf 1999:63-74; Van Dijk 2001:392-8). However, there was a lack of evidence of such political provocateurs in the conflict in West Kalimantan. In fact, the government which in the past always looked for the mastermind (usually dubbed as aktor intelektual) as scape-

\footnotetext{
$5^{6} \quad$ The Commander-in-Chief General Wiranto authorized the re-establishment of seven kodam, which were dissolved in the mid-1980s. The plan was to restore four kodam in conflict-affected provinces during the period 1999 to 2004: one each for Aceh and Maluku provinces, and two for provinces in Kalimantan. The other three kodam were to be restored between 2004 and 2009: Kodam III/Imam Bonjol, Kodam XII/Sam Ratulangi, and Kodam XV/Nusa Tenggara (Rinakit 2005:145). Kodam is the highest regional military command. It usually oversees one or more province. Below kodam is korem, whose authority is mostly at the district level. There are also korem which oversee the whole province, such as Korem 121 in West Kalimantan. The structures below korem are kodim, then koramil and babinsa. Babinsa at village level is staffed by non-commissioned officers.

57 Kodam was re-established in Aceh (20-5-1999) and Maluku (5-2-2002). Kodam Tanjungpura was finally restored on 2 July 2010 with headquarters in Pontianak. Unlike its predecessor, which was exclusively to cover West Kalimantan province, the new kodam is also responsible for Central Kalimantan (http://www.mediaindonesia.com/read/2010/07/02/152955/17/1/KSAD-Pimpin-Upacara-Peresmian-Kodam-XII-Tanjungpura, accessed 26-10-2010).

${ }_{5}^{8}$ Abdurrahman Wahid believed that Soeharto, the former president, was still influential in national politics after his resignation. He visited Soeharto several times to persuade him to ask his supporters to stop instigating conflicts (Van Dijk 2001:393).
} 
goat, believed that there were no such mastermind behind the conflict and that the conflict was purely communal and spontaneous (Akcaya, 26-3-1999). Provocateurs and provocative acts to fuel crowd anger or deliberately spread inflammatory rumours are normal in communal conflicts. While they could be an indication of an 'engineered' conflict, they could also be local people who have put up with 'oppression' and want to settle old scores. No one, including the government, was able to show that the initial conflicts in the province in the 1990s were the results of political manoeuvres. ${ }^{59}$

What about the high level of support the mobs received during the conflict? Human Rights Watch, for instance, reported that a Madurese informant was astonished by the possession of semi-automatic rifles by Dayak attackers in the Sanggau area during the 1997 conflict. According to the informant, those rifles were quite expensive and could only be obtained in Malaysia. The informant also questioned the source of gasoline the attackers used to burn targets (Communal violence West Kalimantan 1997:26-7). The mobs also received food, drinking water, other logistics, and transportation during the conflict. While this could be an indication of the presence of a planned conflict, this support was common during times of conflict. Some common reasons are that the 'supporters' want to protect themselves against the common enemy, to punish a common enemy, or just to show solidarity. Some contribute for their own future gains and hope to be rewarded for their support if the mobs 'win' the conflict. The rest may have no choice because non-contribution may be seen as opposing the mobs: they were forced to choose to be with the mob or against the mob.

\section{MALAY-MADURESE RELATIONS}

One piece of research in the early 1980s found that Malay-Madurese relations were quite close and noticed some degree of assimilation between the two (Sudagung 2001:134-7). However, the number of atrocities committed on the Madurese and the determination not to allow a single Madurese to return to Sambas suggested deep hostility and distrust on the part of the Malays at least in vicinity of Sambas. Malays were report-

59 According to the Governor, the provocateurs in the 1999 conflict were the local population who had accumulated dislike of the Madurese and wanted them out of the village (Akcaya, 27-3-1999). 
ed to have beheaded, mutilated and even cannibalized Madurese victims during the conflict. They had driven virtually all Madurese from Sambas district and rejected their return to the district. Those who were caught visiting the district after the conflict were killed. In such a case in 2002, three years after the conflict, two Madurese went back to Teluk Keramat (Sambas) to sell their land. Fearing for their safety, the Madurese paid security forces to accompany them on their journey. However, Malays in the area found out about their trip and killed them, after forcing the security guards to flee (Purwana 2003:76). In another case, Malays killed a Madurese who returned to Sambas to visit his wife (Davidson 2002:325). Until at least 2006, there were no reports of Madurese resettling in Sambas, although the majority of them wished to return. ${ }^{60}$

The massive conflict and determination to reject the Madurese returning indicated a serious problem in their relations. While he did not see serious problems in their relations, Sudagung saw the potential for conflict between the two. He noted that their harmonious relations were partly because of the restrained character of the Malays (Sudagung 2001:134-7), and therefore not due to amicable relations as such. In fact, as with other ethnic group in the province, Malays shared the negative stereotypes of the Madurese and felt the same level of victimization by them. A former chief of Parit Setia village, the original site of the 1999 conflict, listed 22 cases of Madurese crimes against the Malays and Chinese in Jawai sub-district alone (Saad 2003:103-7). Madurese sources also acknowledged Malay fears. A Madurese leader claimed that the small number of registered Madurese in some neighbourhoods was due to the Malay neighbourhood head's (ketua RT) fear of handling the Madurese registration, and not because the Madurese did not want to register (Petebang and Sutrisno 2000:23, 31).

Some initial episodes in the 1999 conflict showed the arrogant attitude of the Madurese. After attacking Parit Setia, the Madurese attackers yelled 'Malay rice-crackers' and 'three-zero', which meant three

6o The hostility of the Sambas Malays would take many years to heal, and until then Madurese would have to risk their lives when they attempted to return to the district. Wiyata found that by November 2003, none of the Madurese refugees from Sambas in Bangkalan had returned to Sambas. The reason, according to the refugees, was Sambas had closed its doors to the Madurese and that those who returned would be killed. This was very different from the Madurese refugees from Central Kalimantan in Sampang. In 2003, 16,450 Madurese had returned to Central Kalimantan (Wiyata 2003). More recent research argued that opposition to the returning Madurese refugees was supported both by the Malay political elite and general Malay population of Sambas (Cahyono et al. 2006:iv). 
casualties to the Malays and none to the Madurese, to humiliate the Malays (Davidson 2008:127-8). A Madurese in Pemangkat boasted that only two Madurese were needed to obliterate all the Pemangkat Malays (Kapuas, 15-4-1999). They deemed the Malays cowards who only dared to clash with the Madurese after being assured of help from the Dayaks. The echo of arrogance of a few hardliner Madurese travelled far, and incensed more Malays to fight the Madurese.

Madurese and Malays were Muslim, a factor which according to Sudagung (2001:133-7) had partly tended to contribute to harmonious relations between the two. Some scholars observed that Islam had facilitated some Madurese assimilation with Malays and intermarriage between them (Alqadrie 2002a:139; Sudagung 2001:133-5), but they did not demonstrate that a level of assimilation that had taken place. Looking at the trend toward exclusively Madurese settlements, the heavy influx of Madurese migrants, a Madurese culture, resistant to assimilation, and strong stereotyping against the Madurese, assimilation could be seen as more the exception than the norm.

Within the Muslim community, Malay-Madurese relations seemed to be the worst compared to Malay relations with all other Muslim migrants. Research led by Suparlan in 1989, a decade before the MalayMadurese conflict, noted the sharp difference between the Madurese and the Malays in judging each other's religiosity. Both judged the other side as practising impure Islam. ${ }^{61}$ Madurese, for example, were the followers of tarekat (Muslim mystical brotherhoods) which included practices that were different from those of the Malays. ${ }^{62}$ Furthermore, unlike Muslims from other ethnic groups the Madurese usually had their own mosques, dubbed by outsiders as Madurese mosques or mesjid Madura. These mosques used the Madurese language and peculiar rituals which made non-Madurese uncomfortable praying there. The Madurese also usually had their own cemetery, separated from the general cemetery. ${ }^{63}$ These differences might prevent frequent mutual participation by both

\footnotetext{
61 Suparlan et al. 1989:26, 64-5. While Suparlan's research was based on the conditions in Pontianak City, the result could be used as indication for the religious relations between these ethnic groups in other parts of the province.

62 Petebang and Sutrisno 2000:37. The Madurese were closer to Nahdlatul Ulama (NU) practices, while most Sambas Malays were closer to Muhammadiyah practices (Purwana 2003:128-30). NU is usually regarded as a traditionalist Muslim organization, while Muhammadiyah is more progressive.

63 Petebang and Sutrisno 2000:36; Saad 2003:86; Suparlan et al. 1989:26, 64-5.
} 
communities in religious social occasions such as weddings, funerals and other engagements.

These religious differences became pronounced during the conflict in 1999. The Malays, who always considered themselves pious Muslims, were deeply offended when the Madurese cried 'God is Great' (Allahu Akbar) when they attacked the Malays in Parit Setia as if the Malays were not Muslims. To add salt to the wound, the Madurese chose to attack on Idul Fitri, a major festive Muslim day. At the end it was not surprising to see the Malays destroyed the Madurese mosques during the conflict, because after all, they belonged to a 'different' Islam. ${ }^{64}$

Despite harmonious relations on the surface prior to 1999, the underlying relations between the Malays and Madurese were tense. A spark under suitable conditions in 1999 finally ignited those tensions and generated open violence. As in the Dayak-Madurese conflicts, I believe that social and cultural factors were still the most significant in precipitating the Malays-Madurese conflict.

\section{CONFLICT AND THE RISE OF ETHNIC POLITICS}

Ethnic conflicts are sometimes linked with ethnic politics. Such links are relatively clear in ethnic conflicts which have separatist goals, but sometimes less clear in other types of horizontal conflicts. The conflict involving the Dayaks/Malays and the Madurese in West Kalimantan did not appear to have a strong causal connection with ethnic politics. The last conflicts in 1997 and 1999, however, occurred during political crisis and a period of transition as well as during the time of intensifying ethnic politics involving Dayaks and Malays. The conflicts although not initially linked to ethnic politics, had some tie to them. Conflicts had helped the Dayak political elite to step up their pressure on the government to allow more Dayaks in leadership positions in the government, and they tended to unify elements of the Dayaks and intensify their solidarity for stronger ethnic movements. The conflicts also highlighted economic and social justice activities led by some Dayak NGOs. The Malays also apparently benefited from the 1999 disturbances.

64 Purwana 2003; Petebang and Sutrisno 2000. The increasing attack on followers of Ahmadiyah by the Muslims in several places in Indonesia since 2005 is using the same justification. 
Although the 1997 conflict did not start as a political or politicallymotivated conflict, some Dayak elite, particularly those associated with MAD (Dayak Customary Board), used it to extract some political concessions from the government. MAD, which was initially established in 1994, was the only province-wide Dayak organization that had branches down to sub-district level. ${ }^{65}$ When the conflict broke out, MAD and its branches helped the government to organize traditional peace ceremonies ${ }^{66}$ and represented the Dayaks in a series of inter-ethnic negotiations to construct peace. It also established coordination-posts (posko) to help with aid distribution to conflict-affected people.

MAD was well known for their political lobbying during and after the conflict. In order to make its case heard, it organized several intraDayak gatherings and submitted the recommendations of the meetings to the government. One gathering on 16 February 1997 in Pontianak was attended by 250 Dayaks from various backgrounds and organizations, including Dayak public figures and representatives of DAD from Sambas, Pontianak and Sanggau districts. At the end of the meeting, the participants issued a seventeen-point statement to the government. One point demanded the government give equal opportunity to Dayaks to take part in development (mengisi pembangunan), a euphemism for asking for more Dayak positions in the bureaucracy. Another point demanded the government put Dayaks at the top of the legislature candidate list in the upcoming election to increase their chances of being elected. In a paper produced in April 1997, MAD argued that marginalization of the Dayaks was the cause of conflict. As a solution, it urged the government to give greater opportunities and roles to the Dayaks in decision-making processes, and also to provide opportunities for the Dayaks to head

$6_{5}$ It was first named the Customary Board or Majelis Adat (note the absence of 'Dayak') but changed to its current name at the end of April 1997 to include 'Dayak'. This was done partly because of the governor's preference so that the organization had a strong reference to Dayak, because it was indeed a Dayak organization (interviews with Jdh and Awn). At the district level there were Dewan Adat Dayak (DAD, Dayak Customary Council). The first DAD to form was in Pontianak district in May 1985 ('Hasil-hasil musyarawah adat III (musdat III) Dayak Kanayatn Kabupaten Pontianak', 1998, in: Private collection, Pontianak) followed by Sambas district in June 1986 ('Laporan hasil musyawarah adat (musdat) pertama Daya Kabupaten Sambas', 1986, in: Private collection, Pontianak). The official names at district level varied but mostly included Dewan Adat. Pontianak district, for example, used Dewan Adat Kanayatn, while Sambas used Dewan Adat Dayak Sambas. The DAD was independent from MAD, although both maintain a line of coordination.

66 The traditional peace ceremonies were not effective in preventing an escalation of conflict because the ceremonies only involved ethnic elites of questionable legitimacy (Davidson 2002:233-4). 
government offices. ${ }^{67}$ In a letter dated 4 April 1997, MAD demanded that the governor appoint Ignatius Lyong to head the provincial human resources office. ${ }^{68}$ On 1 May 1997, it asked the governor to appoint L.H. Kadir as a deputy governor. ${ }^{69}$

Some Christian organizations which used to detach themselves from the politics of the region also joined the political lobbying. The Association of Indonesian Christian Intelligentsia (PIKI) under the leadership of Mian Simanjuntak tried to increase the role of Christians and Dayaks in government offices. ${ }^{70}$ Together with other Dayak (and Christian) organizations, PIKI issued a political statement to urge the government to give more significant roles to the Dayaks.

The government ignored most of these demands, except the appointment of Ignatius Lyong as the head of Human Resources Office. Despite their lack of success, the political lobbies of MAD and other similar associations continued. During the transition period between 1998 and 1999, they were able to influence the government to appoint Dayaks to head the districts of Sanggau and Pontianak. These two cases will be discussed in the next chapter.

The growing Dayak political lobbies had brought the undercurrents of Dayak - Malay political polarization into the open. The sudden rise of Dayak political leverage, evidenced by the election of two Dayak district heads in 1998-1999 (and later several in other Dayak-dominated districts), worried the top Malay bureaucrats who felt their political careers had been cut short. Worse still was that the government seemed to bow to Dayak pressure. In the eyes of many Malays, the appointment of two Dayak district heads showed that the trend of appointments was based more on ethnic sentiment and mob-pressures rather than on merit or achievement. The Malays believed that as more senior and capable

67 'Laporan pertanggungjawaban Majelis Adat Dayak Propinsi Tingkat I Kalimantan Barat periode 1994-1997', 1997, in: Private collection, Pontianak.

68 This position was highly sought by others and very strategic, especially for the Dayaks who had been complaining about the ceiling on their being recruited for the bureaucracy. The head of this office had a significant role in deciding the number and composition of new civil service recruits and had a role in the promotion of higher ranking echelon bureaucrats.

69 'Laporan pertanggungjawaban Majelis Adat Dayak Propinsi Tingkat I Kalimantan Barat periode 1994-1997', 1997, in: Private collection, Pontianak.

$7^{\circ} \quad$ PIKI at the national level was first established in 1963 in Jakarta. Its profile was revived after the establishment of the Indonesian Association of Muslim Intellectuals (ICMI) in 1990. In West Kalimantan, PIKI was led by Ikot Rinding between 1992 and 1996. Mian Simanjuntak was elected to lead the organization in April 1996 (Akcaya, 18-4-1996). 
bureaucrats they were more suited for those positions than the Dayaks. If ethnic sentiment continued to play a role in the appointment of highranking positions, the opportunities for high-ranking Malay bureaucrats would diminish (Davidson 2008:135-8).

The frustration of the Malay elite was also felt by the Malays at other levels. Malay civil servants and political activists were also dismayed because the appointment of Dayak leadership in their districts could be the start of Dayak dominance in the bureaucracy. These fears became a reality after Bengkayang and particularly Landak districts were established. Soon after the establishment, Dayak civil servants were catapulted into leadership positions in the district bureaucracy.

Both elites and ordinary Malays loathed the Dayak street demonstrations during the district head elections but were not able to launch similar counter-demonstrations. It seemed that the Malays lacked the justification for launching a counter-move against the Dayaks. As was examined previously, the Malays had enjoyed more privileges than the Dayaks in the bureaucracy during the New Order. Unlike the Dayaks, they had no justification to ask for affirmative policies. The Malay demonstrations during two district head elections in 1998-1999 were usually in the form of visits to local DPRD by small groups of individuals and not through mass demonstrations as with the Dayaks.

It was at this juncture that the 1999 conflict between Malays and Madurese broke out. But still, despite their strong motives to counter the Dayaks, the 1999 conflict was not a result of a Malay reaction to rising Dayak political assertiveness as some have argued (Davidson 2008:135-8). The Malays on the street, who initiated group attacks in 1999, aimed simply to take revenge and to teach the Madurese a lesson. This was quite obvious by the lack of reaction of Malays in Sambas to political events where Malay political interests had been upset by the Dayaks. The FKPM, ${ }^{71}$ a Malay youth organization, which had some role in the conflict at a later stage, for example, did not participate in the

${ }^{71}$ FKPM was established at a meeting on 26 January 1999 in Singkawang ('Tim Sebelas pembentukan Forum Komunikasi Pemuda Melayu Kabupaten Sambas: Berita acara', 1999, in: Collection of Zulkarnaen Bujang, Singkawang). A report prepared by the Fact-finding Team of Partai Keadilan Sambas on 22-3-1999 mentioned that the organization was formed through the initiatives of Uray Aminuddin (a staff member of the district office) and Rosita Nengsih, a law graduate. Its aim was to ensure that the perpetrators of the Parit Setia incident would be brought to court. M. Jamras, a local contractor and also a strongman among the local Malays, was appointed to head the forum (Akcaya, 5-2-1999, Partai Keadilan 1999). 
political discussion of the formation of Bengkayang district, where the Dayak interests were growing. The Malays also did not react strongly during the violent Dayak protests during the Pontianak district head election, which contributed to the election of a Dayak district head.

The Malays did not envisage the conflict, let alone plan it, as a way to check the increasing Dayak influence in local politics. The use of conflict as a political bargaining chip against the Dayaks was a later product. After the conflict, Malay organizations such as FKPM and others started to engage in political mobilization quite similar to that of the Dayaks. The Malay challenge to the Dayaks during the Regional Representative (Utusan Daerah) affairs in September and October 1999 had almost led to open conflict between them. Members of FKPM and the Malay Brotherhood Customary Council (Lembayu) played a role in the counter-demonstrations that contributed to holding the Dayaks demands in check. ${ }^{72}$

\section{SUMMARY}

This chapter demonstrates that historical, marginalization and cultural factors have been important underlying factors in hostilities between Madurese and Dayaks. The concentrations of the Madurese, particularly in the conflict-ridden regions, made their relations even worse. Many Dayaks and Malays who lived near the aggressive Madurese felt insecure and intimidated. It seems apparent that the political role of the Madurese was negligible at both district and provincial levels and therefore was not a real threat to the two main ethnic groups, the Malays and Dayaks. The Madurese share in the total economic workforce was small compared to that of the other main ethnic groups. Although Madurese did dominate some occupations in certain areas, it was not the domination but their rough and aggressive behaviour in such economic activities that made the dominance objectionable for the other ethnic groups.

The economic crisis increased the level of poverty among the local population, who became prone to involvement in conflict. The weaken-

$7^{2}$ The FKPM at this stage was still under the name of FKPM Sambas as there had been no provincewide FKPM until November 1999 (Akcaya, 29-11-1999). Lembayu was formed in mid-1999. It had designated several Malay war commanders, resembling the Dayak model. Further on Lembayu and its activities refer to Davidson (2002:351-5). 
ing and change of the regime coupled with rapid democratization contributed to conflict as such changes required adjustment of all political players and opened up antagonistic forces which had been previously repressed by the regime. The advanced telecommunications, a freer press, better road conditions, and the availability of transport were significant in the escalation of conflict.

There is no strong evidence that the conflict was 'engineered' or politically motivated. In both cases, political moves only appeared at a later stage, when ethnic elite became aware of the political opportunities. In both cases the conflicts strengthened the ethnic political movements which appeared during or after the conflicts. 